University of Louisville ThinkIR: The University of Louisville's Institutional Repository

Electronic Theses and Dissertations

$5-2019$

\title{
Curating an American immigrant identity: German and Latin American heritage weekends as placemaking in Louisville, Kentucky, 1974-1980.
}

Sarah Elizabeth McCoy

University of Louisville

Follow this and additional works at: https://ir.library.louisville.edu/etd

Part of the Public History Commons

\section{Recommended Citation}

McCoy, Sarah Elizabeth, "Curating an American immigrant identity : German and Latin American heritage weekends as placemaking in Louisville, Kentucky, 1974-1980." (2019). Electronic Theses and Dissertations. Paper 3191.

https://doi.org/10.18297/etd/3191 for inclusion in Electronic Theses and Dissertations by an authorized administrator of ThinkIR: The University of Louisville's Institutional Repository. This title appears here courtesy of the author, who has retained all other copyrights. For more information, please contact thinkir@louisville.edu. 


\title{
CURATING AN AMERICAN IMMIGRANT IDENTITY:
}

\section{GERMAN AND LATIN AMERICAN HERITAGE WEEKENDS AS PLACEMAKING IN LOUISVILLE, KENTUCKY, 1974-1980}

\author{
By \\ Sarah Elizabeth McCoy \\ B.A., University of Louisville, 2017

\begin{abstract}
A Thesis
Submitted to the Faculty of the

College of Arts and Sciences of the University of Louisville in Partial Fulfillment of the Requirements

for the Degree of
\end{abstract}

Master of Arts in History

Department of History

University of Louisville

Louisville, KY

May 2019 



\title{
CURATING AN AMERICAN IMMIGRANT IDENTITY:
}

\section{GERMAN AND LATIN AMERICAN HERITAGE WEEKENDS AS PLACEMAKING IN LOUISVILLE, KENTUCKY, 1974-1980}

\author{
By \\ Sarah Elizabeth McCoy \\ B.A., University of Louisville, 2017 \\ A Thesis Approved on \\ April 8, 2019 \\ by the following Thesis Committee:

\begin{tabular}{c}
\hline $\begin{array}{c}\text { Thesis Director } \\
\text { Lara Kelland }\end{array}$ \\
\hline Katherine Massoth \\
\hline Frank Kelderman
\end{tabular}




\section{DEDICATION}

I dedicate this thesis to my colleague

Emma Christine Bryan,

who I am so lucky to call my friend. 


\section{ACKNOWLEDGMENTS}

First and foremost, I would like to thank my advisor, Dr. Lara Kelland, for the many drafts and conversations she endured to push me to where I am today. I would not be the scholar and activist that I am today without her inspiration. I would also like to thank my other committee members, Dr. Katherine Massoth and Dr. Frank Kelderman, for their guidance and insight. Without you three, this thesis would not have been possible.

I also want to thank my friends across many states who have listened to me talk about my research endlessly and have encouraged me through graduate school. I want to especially mention my colleague, Emma Christine Bryan. Because of you, graduate school has been a breeze - well as breezy as it could be. You have stuck by my side these last two years, and I am going to miss seeing you nearly every day. You are an amazing, intelligent scholar, and I am excited to see where your career takes you. And I hope to continue going to conferences and talking shop with you.

I want to thank my parents, Joe and Kim Wilborn, for supporting me and believing in me. And for listening to me when I got excited or nervous about my research. Lastly, I want to thank my husband, Ethan McCoy. Without you, I know I would not be where I am today. Thank you for your emotional and financial support. You have put your career on hold so that I could pursue mine, and I am forever grateful for you. Thank you for dealing with me through the many emotions and adventures of graduate school. I love you so much. 


\begin{abstract}
CURATING AN AMERICAN IMMIGRANT IDENTITY:

GERMAN AND LATIN AMERICAN HERITAGE WEEKENDS AS PLACEMAKING IN LOUISVILLE, KENTUCKY, 1974-1980

Sarah McCoy
\end{abstract}

April 8, 2019

The multicultural Heritage Weekends, which began in 1974 in time for the bicentennial, were ethnic festivals in Louisville, Kentucky, and were used by different groups in disparate ways. German Americans and American Latinos used the festivals as placemaking, as they laid claim to the city of Louisville and curated their own interpretation of an American identity. Festival organizers, including city officials, however used the festivals as a way to encourage pluralism, while still promoting hegemony and assimilation. By analyzing newspaper articles and the history of both German Americans and American Latinos in the city, the work of heritage among ethnic groups can be greater understood. However, while also considering the race relations in the city at the time, the Heritage Weekends take on a greater impact in the city as the encouragement of cultural pluralism and the complexities that come along with it arise. 
TABLE OF CONTENTS

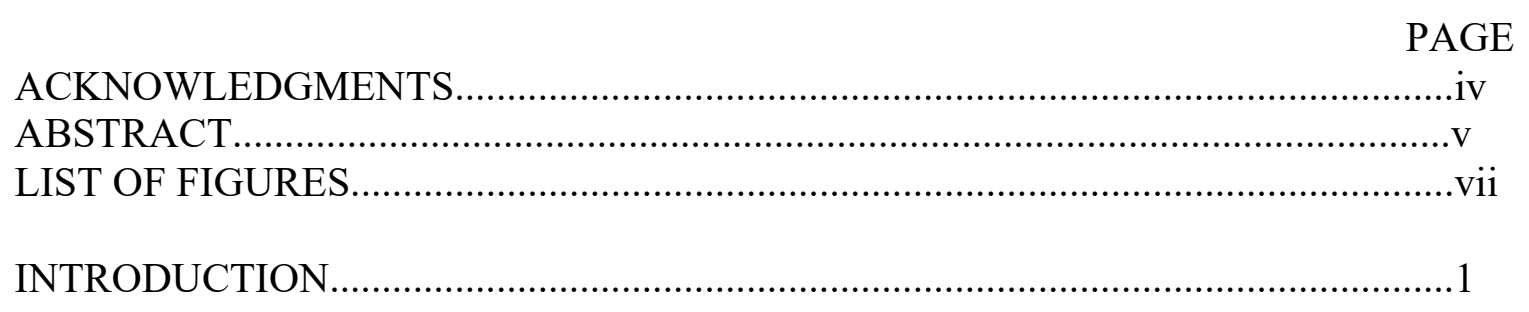

CHAPTER ONE: THE GERMAN HERITAGE WEEKEND......................................12

CHAPTER TWO: THE LATIN AMERICAN HERITAGE WEEKEND.....................25

CHAPTER THREE: RACISM AND EXOTICISM AT THE FESTIVALS..................40

CHAPTER FOUR: PUBLIC HISTORY AND HERITAGE AT THE FESTIVALS......62

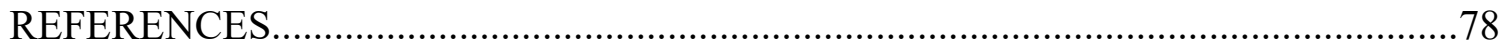

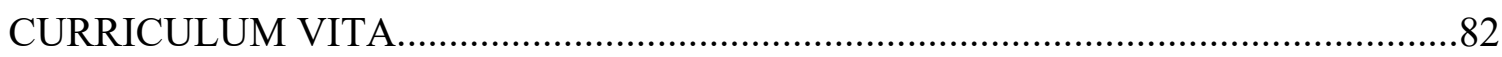




\section{LIST OF FIGURES}

FIGURE

PAGE

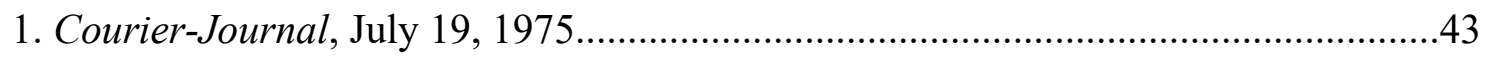

2. Latin American Heritage Weekend.....................................................................50

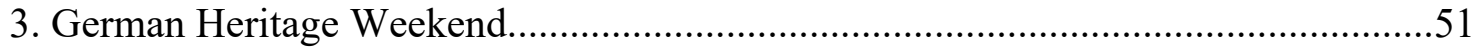

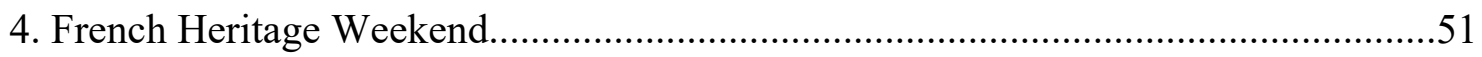

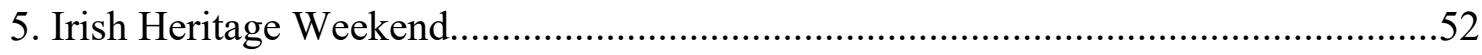

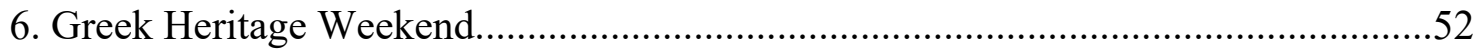

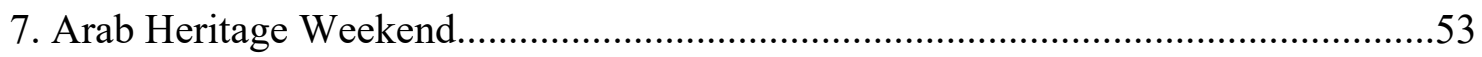

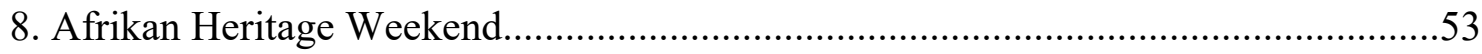




\section{INTRODUCTION}

The Heritage Weekends in Louisville were multicultural festivals celebrating different ethnic communities in the city from 1974 to 1986 . In this thesis I analyze the German Heritage Weekend and the Latin American Heritage Weekend from 1974 until 1980, comparing their representation of history and assimilation, as well as tracing the cultivation of ethnic identities through the discourse and practices of heritage at the festivals. I argue that while the city of Louisville attempted to promote an ideal multicultural society through the festivals, the results of the Heritage Weekends reflect both progressive intentions on the part of planners and prevailing ideas about racial and ethnic othering. One outcome of the festivals was a reassertion of racial hierarchies and stereotypes of ethnic groups, revealing the complexities of and contestations around cultural pluralism. But equally important, festival participants actively curated an ethnic identity through their participation in the festivals. By claiming a symbolic space in Louisville's cultural affairs, festival participants used the weekends as a kind of placemaking in Louisville.

Louisville's Heritage Weekends emerged during the preparation for the nation's bicentennial celebration when the city formed a nonprofit under the Louisville Area Chamber of Commerce called the Louisville Bicentennial Committee (LBC). This organization set forth to celebrate the nation's 200-year anniversary in multiple ways, including Heritage Weekends starting in 1974. According to the executive director of the 
Committee in 1974, John R. Guthrie, these weekends were intended to be "ethnic showcases for the whole city to see."1 Additionally, festival planners wished to "[encourage] ethnic groups to share their heritage with the rest of the city." The festivals sought to cultivate a multicultural society in Louisville by bringing people of different ethnicities together in celebration. From late June to the end of September, Heritage Weekends offered a festival each Saturday and Sunday through the summer, showcasing Irish, Latin American, German, African, Greek, Italian, Arab, Ukrainian and French cultures, and hundreds of thousands attended in the first four years. The festivals were an important aspect of the summer tourism programs in Louisville as the events increased revenue in the city and was part of the downtown revitalization efforts. ${ }^{3}$

Though the LBC oversaw and funded the festivals, each of the groups organized their respective weekends, maintaining some level of control over their identities and representations. Events during the festival included dance and musical performances, exhibits featured arts, crafts, and artifacts, fashion shows highlighted dress and costume traditions, and booths offered food for purchase. The LBC hoped that the festivals would give an "authentic" and apolitical experience to visitors. To do so, festival planners implemented guidelines and policies to govern the festival weekends. ${ }^{4}$ However, because the LBC did "not attempt to influence the programming for individual Heritage Weekends," festival participants enacted agency to create their own interpretation of an

\footnotetext{
${ }^{1}$ Gregg Swem, "From many lands... A summer of ethnic festivals here," Courier-Journal (Louisville, KY), June 23, 1974.

${ }^{2}$ Ibid.

3 “Heritage Weekends," ca. 1976, Immigrants: Heritage Fairs/Weekends Reference File, Archives \& Special Collections, University of Louisville.

${ }^{4}$ Heritage Corporation of Louisville and Jefferson County, "1978 Program Summary," 1978, RG 2, box 4, accession 1981-001C, Heritage Corporation, Louisville and Jefferson County, Volume 1, 572574, Louisville Metro Archives.
} 
American identity for themselves at the festivals. ${ }^{5}$ Individual groups and peoples at each weekend curated their festival so that a certain history was told, and through this, they asserted their own American immigrant identity in the city of Louisville. This American identity looked different for each person and group, as it melded aspects of both their native country and the United States. A new identity for immigrants allowed individuals to stay in touch with their heritage, while also making a claim of citizenship to their new country.

Though multiple ethnic groups participated in the Louisville Heritage Weekends, for this project I compare and the German and Latin American Festivals. I chose these two communities because they both participated in the festivals from the start in 1974, they both received traveling performers from the Smithsonian Institution's "Old Ways in the New World: On Tour" program, and they were paired when the Heritage Weekends were combined in 1980. However, these two communities differ in their respective histories in Louisville, and thus offer instructive case studies for comparison. The German American community was well-established in Louisville since the nineteenth century, though Anglo Americans had quieted their culture in the early twentieth century, whereas the American Latino community, in as much as one can speak of a unified community comprised of numerous nationalities, has only become visible in the last fifty years. Because of this, festival organizers' intentions, as well as the reception of the festivals for various publics, at each respective festival merit engagement. Comparing these two groups facilitates an analysis of the festivals that provides insight into the use

55 “Heritage Weekends,” ca. 1976, Immigrants: Heritage Fairs/Weekends Reference File. 
of heritage among ethnic groups, especially as they operate within racialized discourse and ethnic othering.

Through this analysis of the German and Latin American cultural and social history in Louisville, I argue that the festivals negotiated the question of assimilation and cultural identity in complicated ways. Because the German community had assimilated by the time of the festivals, the German Heritage Festival remained focused on past German customs and culture, which enabled them to depoliticize and ignore twentieth century German history. The Latin American festival, on the other hand, embraced and melded current cultural representations of many countries in Central and South America and the Caribbean. While the representations and curation of each ethnic group differed, the festivals were an important experience of placemaking for two ethnic groups with historical experiences of being othered. Placemaking allowed these groups to lay claim to the city of Louisville as valid citizens, with distinct cultural heritage and identity.

It is important to establish key terms that will be used throughout the following chapters. For the purpose of this project, the term Latino and American Latino will be used to identify those of Latin descent who are immigrants or descendants of immigrants from Latin American countries, including those in Central and South America. Culture, as defined by George Yúdice, is "the structured set or pattern of behaviors, beliefs, symbols, and practices" that inform the way humans live their lives. ${ }^{6}$ In understanding this definition, I see culture in this project in two different forms: tangible and intangible. The tangible culture is that which was on display at the festivals, including food, costume, and artistic performance. Intangible culture, on the other hand, includes

\footnotetext{
${ }^{6}$ George Yúdice, "Culture," in Keywords for American Cultural Studies, eds. Bruce Burgett and Glenn Hendler (New York: New York University Press, 2007), 71.
} 
language, beliefs, religion, and physical appearance. Historically, Anglo Americans have ostracized and oppressed ethnic groups based on their intangible culture, however often accepted and appropriated aspects of the tangible. At the Heritage Weekends, festival participants used this appeal to the tangible, physical culture to assert an American immigrant identity.

Through celebrating heritage, festival participants were able to foster strong immigrant communities and to articulate their own identity, even in the face of racialized stereotypes of Latino communities and the recent history of totalitarianism for German Americans. Scholars of the relationship between identity and history have suggested that ethnic identity contributes to understanding individual identity, which explains to a person who they are and why they are that way. ${ }^{7}$ The festivals functioned as a place for people to come together and create a greater understanding of their ethnic past, their individual characteristics, as well as the start of a collective identity.

Though ethnicity and race are sometimes synonymously used, race is different from ethnicity; yet race defines much of the attitude in the United States, as well as in the Heritage Weekends. While ethnicity defines groups who share common cultural traits and is used to separate people, according to scholar Matthew Frye Jacobson, race "is a theory of who is who, of who belongs and who does not, of who serves what and who is capable of what." ${ }^{\prime 8} \mathrm{He}$ argues that ideas of whiteness have changed over time, especially for

\footnotetext{
${ }^{7}$ Roy Rosenzwig and David Thelen, The Presence of the Past: Popular Uses of History in American Life (New York: Columbia University Press, 1998), 119.

${ }^{8}$ Henry Yu, "Ethnicity," in Keywords for American Cultural Studies, eds. Bruce Burgett and Glenn Hendler (New York: New York University Press, 2007), 103; Matthew Frye Jacobson, Whiteness of a Different Color: European Immigrants and the Alchemy of Race (Cambridge, MA: Harvard University Press, 1999), 6.
} 
European immigrant groups such as Germans, who had the privilege to take on the term “Caucasian" and become white. ${ }^{9}$ Although race is not rooted in scientific evidence, as José Cobas, Jorge Duany, and Joe Feagin argue, it "remains a powerful social determinant in the United States," and has been a tool for the oppression and ostracization of people in the country. ${ }^{10}$ Scholar Ronald Takaki refers to this use of race and white superiority as the "Master Narrative of American History," where Americans have been defined as white and to not be white is to be "different, inferior, and unassimilable." 11 Historian Katherine Massoth expands upon this, writing that "Anglos have been the definers of who belongs to "us' and to 'them." ${ }^{12}$ Hierarchical ideas of race and whiteness are clear in the histories of selected ethnic groups of Louisville as well as in the planning and reception of the festivals. German Americans in Louisville, though once ostracized, were generally accepted as assimilated, white Americans by the time of the festivals, while American Latinos were noticeably racialized throughout the festivals. Still, the memory of WWII was fresh enough that a reinscription of German American heritage was linked to a depoliticized German cultural tradition, and served to secure German-Americans as integrated into the American fabric.

Though the festivals celebrated certain ethnic groups, planners intended to draw a wide audience. In 1970 , Louisville's population was $75.9 \%$ white, with only $4.7 \%$ of the

\footnotetext{
${ }^{9}$ Ibid., 4.

${ }^{10}$ José Cobas, Jorge Duany and Joe R. Feagin, introduction to How the United States Racializes Latinos: White Hegemony and its Consequences, eds. José Cobas, Jorge Duany and Joe R. Feagin (Abingdon, UK: Routledge, 2009), 1.

${ }^{11}$ Ronald Takaki, A Different Mirror: A History of Multicultural America (Boston: Little, Brown and Company, 1993), 4.

12 Katherine Massoth, “"Mexican Cookery That Belongs to the United States': Evolving Boundaries of Whiteness in New Mexican Kitchens," in Food Across Borders, eds. Matt Garcia, E. Melanie Dupuis and Don Mitchell (New Brunswick” Rutgers University Press, 2017), 45.
} 
population being foreign-born or having foreign parentage. ${ }^{13}$ Therefore, supposing that there was a normative or mainstream American culture in the latter part of the twentieth century, and according to the 1970 Census, the festivals were primarily targeted and marketed toward white Louisvillians, even if the events themselves were imagined as the promotion of a multicultural society, one that made space for cultural differences even as it prioritized a hegemonic ideal of assimilated Americanness. Any non-white person, and likely non-Christian, were left out of the normative or mainstream culture in the United States and labeled as "foreign" or the "Other," and thus had a spot in the Heritage Weekends.

While this case study contributes to growing literature on the role of heritage festivals in ethnic communities in the United States, engaging the context of Louisville also provides important insight into the city's heritage festivals. Geographically, Louisville's position between the North and the South caused the city to encapsulate both southern and northern qualities and to develop a hybrid identity. During the eighteenth century, Louisville was not only northern because the Ohio River facilitated trade with Northern and Eastern states, but also southern in that it was a city with a history of enslavement and even as a central hub in the domestic slave trade. Though Kentucky maintained its position in the Union during the Civil War, Louisvillians often identified as southerners during Reconstruction Era because of racial, political, and economic factors. One of the main reasons for this shift was that though many Kentuckians sided

\footnotetext{
${ }^{13} 1970$ Census of Population and Housing: Louisville, KY.-IND.," U.S. Department of Commerce, 1972, 17; Of the "foreign stock," $29.9 \%$ were German, at 5,096 people, and Latinos represented about $8 \%$ with 1,426 people.
} 
with the Union, they were also pro-slavery and "resented the Emancipation Proclamation as a betrayal of their loyalty." 14

As Louisville's African-American population increased during the late nineteenth century, racial tensions also rose, and the divide between white and black communities became more evident throughout the twentieth century. While segregation and Jim Crow were "more fluid, less complete" in Louisville than elsewhere in the southern states, there was still overt racism in the city. ${ }^{15}$ In 1914 , Louisville passed a law that banned anyone from "occupying property on a block on which the majority was another race."16

Although this ordinance was overturned by the Supreme Court three years later, racial prejudice had already laid its foundation in Louisville, and with added job discrimination, Louisville increasingly became culturally and spatially divided by race.

The city, however, continued to look like northern counterparts. Louisville was an industrial city that encompassed diverse religious affiliations, as by the early $20^{\text {th }}$ century, a relatively large population of Catholic and Jewish communities had settled in Louisville. ${ }^{17}$ In 1960, there were 8,500 people of the Jewish faith in Jefferson County, with twelve established synagogues by the end of the twentieth century. ${ }^{18}$ Between 1950 and 1966, the Catholic population of the city established twenty-nine new parishes and in 1966, there were 50,924 students enrolled in Catholic schools. ${ }^{19}$ These demographics

\footnotetext{
14 Tracy E. K'Meyer, Civil Rights in the Gateway to the South: Louisville, Kentucky 1945-1980 (Lexington, KY: University Press of Kentucky, 2009), 3, 4

15 Ibid., 5.

${ }^{16}$ Ibid., 5-6.

${ }^{17}$ Ibid., 7-8.

${ }^{18}$ Lee Shai Weissbach, "Jews" in The Encyclopedia of Louisville, ed. John E. Kleber (Lexington: University of Kentucky Press, 2000), 448.

${ }^{19}$ Joseph T. Merk, "Catholic Schools" in The Encyclopedia of Louisville, ed. John E. Kleber (Lexington: University of Kentucky Press, 2000), 165.
} 
distinguish the city from other southern cities, as they tended to be more Christian Protestant. ${ }^{20}$ Louisville was therefore a progressive southern city.

Louisville holds a distinctive place in the United States as it has related to both the North and the South. When considering the Civil War and racial prejudice that has permeated throughout the U.S., specifically in the southern states, understanding Louisville's position can explain its attitude to immigrants in the twentieth century. Though the city was making its way to be increasingly progressive, the racism of its past still remained in its framework.

As this case study is on Louisville's promotion and reception of and the media followed the Heritage Weekends, the majority of the sources come from the CourierJournal, the main newspaper in the city. The newspaper included advertisements of, as well as interviews from the festivals and included perspectives from both festival participants and festivalgoers. However, the Courier-Journal was known for its liberal perspective and promoting Louisville on the national stage. During the Heritage Weekends, reporters found ways to emphasize ideas of harmony and multiculturalism in the city as a result of the festivals and engaged in more positive aspects of the events, while also emphasizing the racialization of ethnic groups. I will critically engage with this historical source, interrogating the intentions and outcomes of the festivals as portrayed by the newspaper. The rhetoric and language used in the Courier-Journal appealed to the dominant population of Louisville, and thus give insight into the racial attitudes and the importance of placemaking among ethnic groups during this period.

${ }^{20} \mathrm{~K}$ 'Meyer, Civil Rights in the Gateway to the South, 7-8. 
In the following four chapters, I argue that the heritage festivals functioned as spaces of negotiation for racial and ethnic difference and tools that produced identities based on shared heritage. Chapter One focuses on German Americans by briefly tracing the history of German immigration and settlement in Louisville, and then the antiGerman sentiment that followed. Because of this sentiment, which peaked during World War I, German Americans assimilated into Anglo American communities with relative ease due to their perceived whiteness in the United States. The chapter also engages the German Heritage Weekends from 1974 to 1977, emphasizing the stagnant culture of eighteenth and nineteenth century Germany presented at the festivals. This cultural representation was because German Americans curated a heritage that maintained their assimilated, white status. Chapter Two engages the Latin American Heritage Weekends, first sketching the history of American Latinos in Louisville and the United States and discussing the racialization and ostracization of Latinos. It then follows the emergence of the festivals from 1974 to 1977, attending to the significance of the Latino celebration of culture and diversity, as well as contributing to the production of a pan-national identity. Louisville Latinos used the festivals as a tool for placemaking in the city, asserting their cultures and identities as having place in Louisville.

Chapter Three contextualizes the festivals within the racial climate in Louisville, especially within the integration movement in the 1970s. The festivals sought to provide an "authentic" experience through the tangible display of decorations, clothing, entertainment, and food. This chapter also evaluates the offensive rhetoric used in newspapers and interviews, as well as the importance of food at the festivals. At the festivals, food represented an engaging way for festivalgoers to partake and experience 
culture, without having to be physically part of it. In the final chapter, I conclude with an examination of the festivals in the context of public history, arguing that participants in these festivals acted as agents of heritage production and serve as grassroots public historians. The chapter also analyzes the effects of the festival on Louisville as well as the individual communities involved, specifically focusing on pan-Latino community building. Moving forward to the twenty-first century to understand where the heritage festivals are today, the chapter ends with asserting the importance of heritage and identity, and the complexities of a multicultural society.

The Heritage Weekends in Louisville were used by both festival organizers and participants with specific goals in mind. Festival organizers and city officials promoted the festivals to encourage a type of pluralism that still prioritized hegemonic, assimilated Americanness. However, festival participants used heritage as a tool for belonging in the city as they made claim to the city of Louisville and the United States through the festivals. The festivals belonged to a time of racial fear and contestation, therefore ethnic discourse and comprehending the impact of the festivals can only be understood as part of the racial tensions of the 1970s. Consequently, the heritage festivals acted as a place where individual actors had disparate interests and thus the festivals accomplished different goals for each person involved. 


\section{CHAPTER ONE}

\section{THE GERMAN HERITAGE WEEKEND}

Early immigrants in Louisville often created ethnic communities, but later into the twentieth century, sought assimilation. German Americans were one such group that contributed significantly to the city of Louisville and Jefferson County, but also faced discrimination for their heritage in the midst of nativism and World War I. During the mid-twentieth century, German Americans assimilated into Louisville society and were accepted by Louisvillians as white Americans. Because of this, the Heritage Weekends functioned as a place for German Americans to celebrate their heritage while maintaining their assimilated status in Louisville.

Since the mid-nineteenth century, German Americans, and those with German ancestry, have contributed to about one-third of the population in Louisville. ${ }^{21}$ Though immigration as a whole was slow in Louisville in the early nineteenth century, the immigrant population grew with the invention of the steamboat providing a more direct way to reach the city. ${ }^{22}$ German immigrants in America typically moved to areas that

\footnotetext{
${ }^{21}$ Jane K. Keller, Joseph R. Reinhard and C. Robert Ullrich, "Germans" in The Encyclopedia of Louisville, ed. John E. Kleber (Lexington: University of Kentucky Press, 2000), 338.

${ }^{22}$ Thomas P. Baldwin, "The Public Image of Germans in Louisville and in Jefferson County, Kentucky, 1840-72," Yearbook Of German-American Studies 29, (January 1994): 84.
} 
were more rural over urban centers, so Kentucky was appealing to many. ${ }^{23}$ Furthermore, the small percentage of enslaved African Americans in Louisville attracted immigrants because it meant there would be less competition for work and a better chance at finding a job to support their families. ${ }^{24}$ Adding to the population, many Germans came to the United States as refugees after the failed 1848 Revolution in Germany, arriving in many cities including Louisville; these immigrants were called "Forty-eighters," and were typically more liberal and politically outspoken than previous German immigrants. ${ }^{25}$

The growing American "Know-Nothing” party, an anti-foreigner, anti-Catholic party, in Louisville targeted the German American population in the mid-nineteenth century. Catholic immigrants frightened nativists, as they viewed Catholicism as being a threat to democracy and believed Catholics could not be truly democratic citizens. ${ }^{26}$ In addition to negative views about immigrants, including their use of alcohol, physical appearance, and manners, Anglos came to channel their problems with immigration through German and Irish immigrants. ${ }^{27}$ Tensions rose in the summer of 1855 as an election drew near, and on August 6, Election Day, Know-Nothing members harassed non-American party members attempting to vote and then violently attacked German businesses and homes, and an Irish neighborhood. This attack was known in Louisville as "Blood Monday." The event resulted in the deaths of at least twenty people and impacted immigrant communities for at least a generation. ${ }^{28}$

\footnotetext{
${ }^{23}$ Kevin Kenny, "Race, Violence, and Anti-Irish Sentiment in the Nineteenth Century," in Making the Irish American: History and Heritage of the Irish in the United States, eds. J.J. Lee and Marion R. Casey (New York: New York University Press, 2006), 367.

${ }^{24}$ Baldwin, "The Public Image of Germans in Louisville," 84.

${ }^{25}$ Keller, Reinhard and Ullrich, "Germans," 338.

${ }^{26}$ Jacobson, Whiteness of a Different Color, 70.

${ }^{27}$ Kenny, "Race, Violence, and Anti-Irish Sentiment in the Nineteenth Century," 365, 367.

${ }^{28}$ Keller, Reinhard and Ullrich, "Germans," 338-339.
} 
Local sentiment towards Germans was fickle during the second half of the $19^{\text {th }}$ and the early $20^{\text {th }}$ century. After the Bloody Monday Riot, Germans in Louisville often felt they were not welcome and either left the area or tried to be less noticed, though this quickly changed. Opinions of German immigrants altered during the onset of the Civil War. Because many German immigrants were pro-Union and anti-slavery, they supported Kentucky for staying in the Union and many joined the Union army. Public sentiment continued to favor Louisville Germans through the late nineteenth century. In 1865, Louisville elected a German-born mayor and German organizations flourished. ${ }^{29}$

However, this view of German Americans did not last long. When World War I began, most Americans sided with the Allies, and German Americans were once again attacked for their heritage. In Louisville, Henry Watterson, a renowned Courier-Journal editor, took up a firm anti-German position. ${ }^{30}$ In his editorials, Watterson used the term "Hun" to refer to Germans, and quickly took to the press' "War on the Kaisers." ${ }^{31}$ In an editorial Watterson claimed that the German propaganda from Berlin "has been only too successful in misleading the German-Americans." ${ }^{32}$ Accordingly, Watterson produced a four-part lecture in the Courier-Journal, instructing Germans on how to be proper American citizens. In response to Watterson's many editorials, reporter J.J. Williams wrote in the Cincinnati Volksblatt, "It is sad and also amusing when a man who himself is ignorant wishes to give instruction to others. With his attacks on the Kaiser and his

\footnotetext{
${ }^{29}$ Ibid., 339.

${ }^{30}$ Ibid.

${ }^{31}$ John E. Kleber, "Anti-German Sentiment During the World Wars," in Germans in Louisville: A History, eds. C. Robert Ullrich and Victoria A. Ullrich (Charleston, SC: The History Press, 2015), 189; Arthur Krock, The Editorials of Henry Watterson (New York: George H. Doran Company, 1923), 377.

${ }^{32}$ Henry Watterson, “America Steadfast,” Courier-Journal (Louisville, KY), Feb. 9, 1917.
} 
opinions about the political condition of Germany, Watterson places himself on the same level with the low class of Americans who continue to talk of the 'Damned Dutch." ${ }^{33}$ Despite pushback, Watterson continued to attack what he called the "German Colony" of America and was certain German Americans would swear allegiance to Germany. In one editorial, Watterson even reminded local immigrants of the Bloody Monday events, using the memory of the violence as a threat, reminding Germans that if they were to abandon their adopted country, they would pay the consequences. ${ }^{34}$

This kind of anti-German sentiment was common across the United States during World War I. As a result, many German-owned businesses changed their names so that they would not be identified as German. Furthermore, people altered their surnames, renamed streets, teachers and preachers stopped using the German language, and libraries removed German books. ${ }^{35}$ "100 percent Americanism" became the cry of the city and Germans lined up in the basement of Louisville's city hall to be registered as "enemy aliens," while their personal information was printed in local newspapers. ${ }^{36}$ The government as well as local citizens, such as Watterson, pressured German Americans in Louisville to leave behind their culture and be completely "American." Thus, World War I and the sentiment that accompanied it quieted the German culture, and local German Americans assimilated.

\footnotetext{
${ }^{33}$ J.J. Williams, "Race Hatred: An American Organ of Pro-Kaiserism and Pan-Germany Explodes the Vials of Its Wrath Upon a Fried of German People and Vaterland," translated from the Cincinnati Volksblatt, Courier-Journal (Louisville, KY), Sep. 6, 1914.

${ }^{34}$ Ronald R. Alexander, "Henry Watterson and World War I," The Filson Club History Quarterly 52, no. 3 (July 1978): 256-7.

${ }^{35}$ Keller, Reinhard and Ullrich, "Germans," 339; Kleber, "Anti-German Sentiment During the World Wars," 191-2.

${ }^{36}$ Kleber, "Anti-German Sentiment During the World Wars," 190.
} 
In this case, Louisville was not special. Anglo Americans across the country ostracized and oppressed German Americans during the early twentieth century. Scholars such as Melvin Holli have viewed this time in history as the moment that provoked Germans to assimilate fully into American society. Holli demonstrates this through his case study of Chicago, saying that it once was a city full of German history and culture, and likewise in Louisville, the German population in the late-nineteenth century had greatly contributed to the economy and fit well within the city's fabric. However, during World War I, U.S. society attacked the language, customs, and food of German Americans. From a point when schools were sometimes bilingual to where German was banned from schools in twenty-six states, Holli argues that German Americans were the only ethnic group to be destroyed or "de-ethnicized" so quickly by a single event in U.S. history. ${ }^{37} \mathrm{He}$ claims that what little German culture remained in the U.S. after WWI was wiped out during the Second World War, causing for the total destruction of German culture and assimilation of German-Americans.

Christian Wilbers, however, rejects Holli's argument. Instead, he asserts that Germans were actively taking part in their culture despite the oppression they may have experienced in America during this time. Wilbers argues that as German Americans, they were able to be both German and American, and saw their culture as such. He asserts that when the "war against the German people" became a powerful force in America, instead of assimilating, German Americans came together and negotiated their place in American society so that they could be both German and American. ${ }^{38}$ My research on Louisville

\footnotetext{
${ }^{37}$ Melvin G. Holli, "German-American Ethnic Identity from 1890 Onward: The Chicago Case," The Great Lakes Review 11, no. 1 (1985): 7, 9.

${ }^{38}$ Christian Wilbers, "Saxon? German? American? Negotiating Germanness and Belonging in the United States, 1935-1939," German Studies Review 39, no. 1 (February 2016): 82, 83, 87, 94, 95.
} 
confirms Wilber's arguments of assimilation and moves scholarship away from Holli's assertions, as Louisville Germans maintained their heritage through the World Wars.

In Louisville, though German Americans found ways to continue interacting with their heritage through clubs, their outward expression of German culture was subdued. German Americans increasingly asserted themselves not as German-Americans, but Americans. Louisville's German Security Bank simply changed to Security Bank, and German Insurance Bank changed its name to Liberty Insurance Bank. ${ }^{39}$ Some German churches closed shortly after the war, and street names were changed, such as Green Street to Liberty Street in $1918 .{ }^{40}$ The only remaining German newspaper of Louisville, the Louisville Anzeiger, printed its last issue in 1938. German Americans publicly distanced themselves from German heritage as much as possible and identified more with Anglo American culture.

Regardless of the level of assimilation among German Americans, or the reasons for it, they were able to rather easily because of their whiteness. According to Jacobson, German immigrants were less likely to see the assertion of a unified German race as useful and therefore did not actively participate in conserving the German "race." Despite this, they were inherently more likely to be welcomed as white Americans. In turn, Germans immigrated to America with ease because they were considered white and part of the Caucasian race. ${ }^{42}$ By the twentieth century, says Jacobson, Germans had

\footnotetext{
${ }^{39}$ Keller, Reinhard and Ullrich, "Germans," 339.

${ }^{40}$ Kleber, "Anti-German Sentiment During the World Wars," 193.

${ }^{41}$ Jacobson, Whiteness of a Different Color, 47.

${ }^{42}$ Matthew Frye Jacobson, Barbarian Virtues: The United States Encounters Foreign Peoples at Home and Abroad, 1876-1917 (New York: Hill \& Wang, 2001), 192.
} 
become "honorary Anglo-Saxons," assuming the privileges of “"old-stock” Americans." Some scholars, such as Ronald Bayor, disagree though, saying that lighter-skinned European immigrants were not fully considered white until the racial tensions of the 1950s, creating a white identity group in contrast to African Americans. ${ }^{44}$ In fact, Bayor and Jacobson assert the reason that Germans and other European immigrants were considered "white" was because of non-white groups in America. ${ }^{45}$ Bayor, however, says that despite being considered white, "nationality-based ethnic" identities continued to exist throughout the twentieth century. ${ }^{46}$ Louisville's German Americans certainly were an example of Bayor's argument. German Americans in Louisville had assimilated by the time of the festivals, and Anglo Americans fully considered them as white Americans as well. Through the power and legitimacy of whiteness, German Americans reclaimed German culture while also maintaining their assimilated status.

In the mid-to-late- twentieth century, German Americans in the city continued to cultivate their identity through clubs like the German American Club, the Social Male Chorus, and the Louisville Turners. From the start of the Heritage Weekends in 1974, German Americans participated every single year. The first year of the summer festivals, the Germanic Heritage Weekend consisted of entertainment, a dog show, exhibits, and food that included bratwurst, beer cheese, and sauerkraut. The exhibits included artifacts such as beer steins, music boxes, dollhouses with wooden furniture, and Christmas

\footnotetext{
${ }^{43}$ Ibid.

${ }^{44}$ Ronald H. Bayor, "Another Look at 'Whiteness': The Persistence of Ethnicity in American Life," Journal of American Ethnic History 29, no. 1 (2009): 13.

45 Jacobson, Whiteness of a Different Color, 7-9.

${ }^{46}$ Bayor, "Another Look at 'Whiteness,"” 14.
} 
decorations, all from the nineteenth century. ${ }^{47}$ There was also plenty of entertainment from bands, such as the Bavarians, the Polka Dots, and the Dan Krekel Orchestra. ${ }^{48}$

The German Heritage Weekend of 1975 and 1976 evolved from its previous year as entertainment and food were more plentiful. "There will be German music; German dance; German costumes; German food; and maybe even a German biergarten,” a Courier-Journal writer reported. ${ }^{49}$ Like the year before, exhibits showed off artifacts such as steins and hand-carvings. For entertainment though, the Turners, a local gymnastic troupe performed, as well as German performers from the Smithsonian Institution's 1975 Festival of American Folklife Tour. ${ }^{50}$ The food options of the second year's festival included potato salad, German meatballs, and Frankfurters added to the original menu. ${ }^{51}$ The 1976 festival continued in fashion with many of the same local performers, exhibits, food, and many different wines. The exhibits also included traditional German garb, hand-painted tiles, and paintings. ${ }^{52}$

The 1977 festival was definitely the peak of the Heritage Weekends for the German American contingent, as professionally curated exhibits located in renowned cultural organizations across the city were part of the festivities. These exhibits were significant because this was a first for the German Heritage Festival, or any other festival for that matter. At the festival, Louisville welcomed Josef Hofmann, the vice-mayor of Mainz, Germany (Louisville's soon-to-be sister city), and Dr. Helmut Presser, the director and curator of the Gutenberg World Printing Museum in Mainz. Dr. Presser

\footnotetext{
47 “Achtung! Song, Dance, Food at German Fest," Courier-Journal (Louisville, KY), July 11, 1974.

${ }^{48}$ Ibid.

49 “"The Leisure Almanac,” Courier-Journal (Louisville, KY), July 10, 1975.

${ }^{50}$ Ibid.

${ }^{51}$ Lynn Bynum, "Hundreds Attend Heritage Weekend: Louisville Riverfront Area Transformed into Biergarten for German Festival," Courier-Journal (Louisville, KY), July 13, 1975.

52 "What's Going On: Oom-pah-pah," Courier-Journal (Louisville, KY), Aug. 1, 1976.
} 
brought with him to the States an exhibit from his museum, which was displayed at Louisville's Museum of Natural History and Science during the week of the festival. This exhibit centered on a hand-decorated Gutenberg Bible from the fifteenth century, one of only 200 original bibles printed by Johannes Gutenberg. In addition to the bible was "Die Frau," an exhibit at the American Life and Accident Insurance Building that displayed a "special book collection compiled in Germany in 1975 to commemorate the Year of the Woman." ${ }^{, 3}$ Rather than this being an outdoor festival with small exhibits in a nearby building, the German Festival spread out to include much more than it had in previous years and expanded out to more parts of the city's infrastructure.

Through the exhibits at the 1977 Heritage Weekend, festival participants curated an identity for German Americans, so they could be seen as having a place in United States history. Along with the exhibits, Dr. Presser spoke about German history at a preview party the night before the festival began. There he talked about Gutenberg and the "art of printing." 54 He was noticeably passionate about what he had devoted his career to and even began speaking so quickly in German that he forgot about his translator. Despite his excitement, Dr. Presser was able to tell a room of a few hundred people about Germany and its contribution to American society. ${ }^{55}$ Dr. Presser's addition to the German Heritage Festival, through his lecture and exhibits, added to the festival as festivalgoers were able to see the contributions Germany had made to the world and to America. Along with this theme, the 1977 festival also featured an exhibit located in the same building as "Die Frau," entitled "America Through the Eyes of German Immigrant Painters," which

\footnotetext{
53 "German-heritage Weekend," Courier-Journal (Louisville, KY), July 29, 1977.

${ }^{54}$ John Finley, "Typecast: Gutenberg Bible Joins German Heritage Show," Courier-Journal (Louisville, KY), July 31, 1977

${ }^{55}$ Ibid.
} 
showed "American impressions" by eighteenth- and nineteenth-century German painters. ${ }^{56}$ In addition to the exhibits, the festival showed the film Americans from Germany, "which shows the German influence on American art and science."57

From 1974-1977, the German Heritage Festival was a favorite among festivalgoers. In the first year alone, 30,000 people came to the festival to enjoy the activities. The number of attendees more than doubled in the coming year with 64,000 participants in 1975. Attendance continued to grow, with 90,000 and then 130,000 in 1976 and 1977, respectively. In fact, the German festival was one of the most well attended festivals in all of the Heritage Weekends. ${ }^{58}$ This excited workers and organizers of the festival. On the second day of the festival in 1975, a St. Joseph's Catholic Church volunteer who helped with the food said happily, "we served 4,500 yesterday, and we're aiming for 6,500 today," compared to the 7,000 they served the whole weekend the year before. $^{59}$

Food was an important aspect of the German Heritage Weekend. Besides being an avenue for German Americans to share their consumable culture while also making some money, food was a focal point for many of the festival participants as it was a chance to try something new and exciting from a different community. Lynn Bynum, a CourierJournal writer reported in 1975, "The smells of sauerkraut and bratwurst were in the air as hundreds of visitors lined up to purchase a large variety of German dishes. Under the

\footnotetext{
${ }^{56}$ Gregg Swem, "The Heritage Festivals: It's 'Vive la France’ Time Down by the Old Ohio," CourierJournal (Louisville, KY), June 5, 1977; "German-heritage Weekend."

57 "German-heritage Weekend."

58 "Heritage Weekends," ca. 1976, Immigrants: Heritage Fairs/Weekends Reference File.

${ }^{59}$ Ken Loomis, "German Sprinkling: Festival Spirit and Appetite Undampened," Courier-Journal (Louisville, KY), July 14, 1975.
} 
canopies lining the walkways of the plaza, people stood and devoured frankfurters and bratwurst wrapped in pumpernickel bread, cups of potato salad and sauerkraut and plates of German meatballs. ${ }^{" 60}$ Another reporter, Ken Loomis, also discussed the significance of food at the German festival, "Some music makes you want to sing, some makes you want to dance. But judging by the behavior of the thousands who flocked to Riverfront Plaza yesterday, German music has a special appeal: It makes you hungry." Loomis continued:

Hordes of people at the final day of the German Heritage Weekend either clustered around food booths or into long lines, waiting to surround bratwurst, franks, sauerkraut, cheese and apple pastry. The culinary victor appeared to be the simple but copious bratwurst sandwich, a sausage as big as a butcher's thumb, wrapped nakedly in a slice of break like a blimp in a bikini. As the tuba of the Langenschlitach Brass Choir and Dance Ensemble oompahed from the plaza, stomachs rumbled in three-quarter time, and the frantic volunteers of St. Joseph's Catholic Church worked heroically to keep the bratwurst coming. ${ }^{61}$

Food was a major point at the festival and allowed people to enjoy German culture through eating. For this reason, the food choices became more plentiful in the coming years, as did the amount sold. German food, then, became synonymous with German culture among festivalgoers. In turn, eating the food meant experiencing the culture.

Festival planners showcased an array of cultural expressions which represented an older, traditional German culture. For example, the Smithsonian group that came to perform at the 1975 festival had an interpreter, Tony Hellenberg, who, according to Bynum, "explained that the music performed throughout the day by the three native German groups was played in the 1800 s as German court music." ${ }^{62}$ This nineteenthcentury era performance was not exclusive to the Smithsonian group. The majority of

\footnotetext{
${ }^{60}$ Bynum, "Hundreds Attend Heritage Weekend."

${ }^{61}$ Loomis, "German Sprinkling."

${ }^{62}$ Bynum, "Hundreds Attend Heritage Weekend."
} 
performances at the German festivals focused on this older music genre, playing the oompah-pah of the 1800s. The exhibits also focused on traditional German objects of the eighteenth- and nineteenth-centuries. In the 1974 exhibit, a highlight was the "traditional Christmas tree, decorated with old German ornaments and circled by a miniature Bavarian village and an electric train." ${ }^{93}$ Though it is in the nature of exhibits to display older objects, as in a museum, the exhibits at festivals such as these did not have to as they were meant to display tangible culture. However, the objects that were shown at the German festival were centuries old and represented a static image of German American culture.

Participants of the German Heritage Weekend established German Americans as an essential part of Louisville's cultural makeup through the curated image at the festival. During the first three years of the festival, participants displayed their communities with a tangible, fixed culture through the food and entertainment of the festival. Festival participants, though, more actively curated the image of German Americans in the 1977 festival as more people attended the festival. Participants depicted German immigrants as an earlier immigrant group from the nineteenth century that was fully assimilated into American society by the mid-twentieth century. German Americans thus asserted an American identity at the festival that centered on their whiteness and assimilated status. Only a few decades before the festivals, German Americans were despised and treated as a threat to American democracy. By focusing on an older, more cheerful and less threatening cultural moment of their past, German Americans were able to put the less desirable aspect of the past behind them and simply identify as well-assimilated white

63 “Achtung! Song, Dance, Food at German Fest." 
Americans. To do this, festival participants carefully mediated and curated the exhibits and displays to control this image of German Americans. They could do this because of their link to whiteness and the racial divide that developed in the 1960 s. ${ }^{64}$ The German culture celebrated in the 1970s was frozen in time, representing that of past generations without a tie to the currently divided Germany, or the recent fascist Germany. Because of this, the German Heritage Festival in Louisville was widely popular and easily celebrated, with very little mention of Germany's troubling past.

${ }^{64}$ Jacobson, Whiteness of a Different Color, 7-9; Bayor, “Another Look at 'Whiteness,"” 14. 


\section{CHAPTER TWO}

\section{THE LATIN AMERICAN HERITAGE WEEKEND}

As a smaller and more recent, twentieth century immigrant community, American Latinos were more othered than German Americans in Louisville. Because of the racialization of Latinos in the United States, Louisville Latinos used the Latin American Heritage Weekend to claim their place in Louisville society, and by extension into the nation and citizenship. In doing so, they emphasized the diversity among Latino cultures while also nourishing a pan-Latino community in the city.

Latino immigration into the southern states, specifically the Southeast, was slow compared to other areas of the United States. Though Latino immigrants have been immigrating to this area since the early twentieth century, scholars have only recently noticed the Latin American population in the U.S. South. ${ }^{65}$ In the 1980s and 1990s, as with across the southern states, many Mexican and Central American workers came to Kentucky to work on tobacco farms. During the off-season, these workers settled in Louisville, making the Latino population the largest it had ever been in the city by $2000 .^{66}$

\footnotetext{
${ }^{65}$ Julie M. Weise, Corazón de Dixie: Mexicanos in the U.S. South since 1910 (Chapel Hill, NC: The University of North Carolina Press, 2015), 3.

${ }^{66}$ Miguel Lagunas, "Latin Americans" in The Encyclopedia of Louisville, ed. John E. Kleber (Lexington: University of Kentucky Press, 2000), 501.
} 
As for the twentieth century, American Latinos made their way to the city in different ways, usually through familial relations. During World War II, some Latino soldiers stationed nearby at Fort Knox married local Anglo women and stayed in the area, while other soldiers married Latino women and settled in Louisville after the war. Additionally, Latin American students came to the University of Louisville for their studies during the early- to mid- twentieth century, and some stayed where they found spouses and jobs. Therefore, much of the Latino immigration into the city was centered on marriage and familial networks. Because of this, Miguel Lagunas argues that there was not an established pattern for organized immigration from Latin America to the city. ${ }^{67}$ Each person decided where they were going to live in Louisville based on who they knew and why they were moving to the city, and so American Latinos were not concentrated in a certain area and did not have a "Latin Quarter" that is typical of many other cities. ${ }^{68}$ Lagunas' argument proves useful in understanding the foundation of American Latinos in Louisville, as well as the lack of Latino organizations. Many Latinos in the area stayed in their neighborhoods and their personal networks, without contact with others who also identified as Latino.

The organization among American Latinos began to change in the 1960s and 1970s. The Latino population grew to a few thousand in the 1960s, as Cuban immigrants and Latino medical professionals made their way to Louisville. By the 1970s, the Latino population in Louisville was the largest it had been, and Latinos represented the minority group with the most contributors to the local economy, as well as professionals who

${ }^{67}$ Ibid., 500-501.

${ }^{68}$ Ibid. 
practiced their profession, relative to their population. ${ }^{69}$ In response to the growth in population, a professor of Spanish language at the University of Louisville, Fortuna Gordon, met with other Latinos in the Louisville area, including America Dunham, Miguel Lagunas, and Delmo Durig, where they discussed creating a club where Latinos could have a place to socialize and express both their tangible and intangible culture. They soon formed the Community Club of the Americas in the early 1970s, which later changed its name to the Latin American Club of Louisville (LAC). This club was the first of its kind for American Latinos in Louisville and became the sponsoring organization for the Latin American Heritage Weekends. ${ }^{70}$

In the United States, Latinos have always faced discrimination, and this ostracization is a central theme in the literature. Lorrin Thomas argues that being accepted in the United States has nothing to do with citizenship, but rather with performing whiteness; looking white and "acting" white have always been essential to being accepted in the United States. ${ }^{71}$ This has been an issue for Latinos across the United States as no matter if they were born in the country, given citizenship through the annexation of their land, such as Tejanos and Puerto Ricans, or gained their citizenship after immigrating to the U.S., they were still discriminated against and treated as noncitizens. Furthermore, since Latin American countries are so close in proximity to the U.S., where many immigrants share a border or continent with their native land, they have a different kind of immigrant experience; the closeness to their home country allows

\footnotetext{
${ }^{69}$ Ibid, 501.

${ }^{70}$ Ibid.

${ }^{71}$ Lorrin Thomas, Puerto Rican Citizen: History and Political Identity in Twentieth-Century New York City (Chicago: University of Chicago Press, 2010), 7.
} 
their language and identity to be maintained. ${ }^{72}$ Because of this, they are treated as outsiders and labeled as "unassimilable," constantly being berated and subjected to white dominance. ${ }^{73}$ This tension around assimilation was present across the United States in the 1970s and prefaced the Latin American Heritage Weekends, as Latinos had to live with being treated as the Other in the United States and their intangible culture was not generally accepted by Anglo Americans. In response, Latinos who organized the Latin American Heritage Weekend ensured that they were rejecting those racialized ideas and asserted themselves as a valid people in the United States.

Though Latinos have been racialized since before the Treaty of Guadalupe Hidalgo in 1848, they are not at the forefront of race relations in the United States, as there is a greater focus on the divide between Anglo Americans and African Americans. William Flores and Rina Benmayor argue that race is often cast in terms of white and black difference, "eclipsing the complexities of the Latino experience, an experience which is racial, cultural, and linguistic." 74 Cobas, Duany, and Feagin expand upon their argument, observing that since Latinos have been racialized in the country, they are defined as a separate racial group and are seen as physically and culturally different. ${ }^{75}$ The racialization of Latinos has thus allowed white leaders to belittle Latinos. Therefore, argues Cobas, Duany, and Feagin, Latino "racialization also entails their incorporation into a white-created and white-imposed racial hierarchy and continuum, now a century

\footnotetext{
${ }^{72}$ Takaki, A Different Mirror, 9.

${ }^{73}$ William V. Flores and Rina Benmayor, introduction to Latino Cultural Citizenship: Claiming Identity, Space, and Rights, eds. William V. Flores and Rina Benmayor (Boston: Beacon Press, 1997), 2; Takaki, A Different Mirror, 4; Cobas, Duany and Feagin, How the United States Racializes Latinos, 5.

${ }^{74}$ Flores and Benmayor, Latino Cultural Citizenship, 1.

${ }^{75}$ Cobas, Duany, and Feagin, How the United States Racializes Latinos, 1.
} 
old, with white Americans at the very top." ${ }^{.76}$ White racial dominance has subjected Latinos to racist legislation, the taking of land, and intervention in Latin American countries; all because it is seen that Latinos are "inferior" to white America. ${ }^{77}$ Latinos were aware of their racialization in the United States, and were constantly subject to prejudice and white supremacy. American Latinos in Louisville thus used the Heritage Weekends as an opportunity to establish their place publicly, and to create their own immigrant identity.

Latino racialization also produced increasing stereotypes and ostracization towards American Latinos in the United States. During the era of Jim Crow in the south, Latinos came to understand their own segregation as "Juan Crow." ${ }^{" 78}$ Furthermore, according to Flores and Benmayor, "borders, real and symbolic, jut seemingly ever higher and wider to encapsulate the perceived threat from Latinos. So Latinos, even those who trace their ancestry and citizenship in the United States back for many generations, often feel rejected as full and equal citizens of the country in which they were born." ${ }^{.79}$ To further this, the Spanish language has always been under attack in the U.S., and Englishonly legislation has been implemented across the country. ${ }^{80}$

The U.S. media further cast Latinos as a threat to Anglo Americans, depicting them as foreign and dangerous. ${ }^{81}$ The government and media have decidedly categorized Latinos separate from non-Hispanic whites and blacks. This racialization of Latinos has

\footnotetext{
${ }^{76}$ Ibid.

${ }^{77}$ Ibid., 4, 12.

${ }^{78}$ Weise, Corazón de Dixie, 3.

${ }^{79}$ Flores and Benmayor, Latino Cultural Citizenship, 2.

${ }^{80}$ Ibid., 10.

${ }^{81}$ Cobas, Duany and Feagin, How the United States Racializes Latinos, 7.
} 
subjected them to political control and exploitation by Anglo Americans, while English has become recognized as the official language of the country, causing the use of Spanish to be considered "foreign" and "un-American." ${ }^{82}$ Due to the continued racialization of a people who speak and look different, Anglos have ostracized and oppressed Latinos. ${ }^{83}$ Despite such efforts, though, they remain a prominent community in the U.S. and many hold on to their tangible and intangible culture. This is displayed in the Latin American Heritage Weekends, as hundreds of Latinos came to the festival to communicate and express themselves through their tangible culture.

In the 1970s, Louisville media also reinforced the racialization of Latinos. In the Courier-Journal during this decade, there were articles that referred to Latinos as "Illegals" and how because the U.S. had "the most generous immigration policy in the world," there was an immigration "problem." ${ }^{84}$ In one such article, the author James Reston attacked Latino immigrants and stated that the jobs "Illegals" (referring to Latinos) took could instead be filled by "jobless American teen-agers" or "black American youths who are out of work." ${ }^{85}$ In another article, after reporting of an illegal Mexican immigrant being detained in the Louisville area, James Gray, a federal immigration official, said that illegal Mexican immigration was a "big problem" in the state, and suggested to stop "the flood of illegal aliens," they should "dry up the reason they come, employment. ${ }^{" 86}$ Even though these articles center on illegal immigration, the

\footnotetext{
${ }^{82}$ Cobas, Duany and Feagin, How the United States Racializes Latinos, 8, 12

${ }^{83}$ Takaki, A Different Mirror, 4.

${ }^{84}$ James Reston, "Myths About Welfare and Immigration Help Make This 'America the Unknown," from New York Times, Courier-Journal (Louisville, KY), May 13, 1977.

${ }^{85}$ Ibid.

${ }^{86}$ Bob Johnson, "Higher Wages Lure Aliens to U.S.," Courier-Journal (Louisville, KY), May 8, 1978.
} 
authors and interviewees referred to it as a problem and to Latino immigrants as "Illegals." ${ }^{87}$ Racialization and animosity toward Latinos was present in Louisville as it was in the rest of the country.

American Latinos were present from the start of the summer festivals in 1974 with the Latin American Heritage Weekend, and the festival acted as a catalyst for creating a pan-Latino identity in Louisville. The LAC, whose goal was "to get together people of Spanish or Latin American backgrounds" and share customs, coordinated the Latin American Heritage Festival. ${ }^{88}$ During this time, the LAC had seventy-five families representing twenty countries. In 1975, Ernest Gittli, the chairman of the Latin American Heritage Committee and LAC representative, said that there were "several thousand persons in the area who were either born in a Latin American country or have worked there." He explained that the goal of the Heritage Weekend was to bring together those people and to add to the forming pan-Latino community, with an invitation to join LAC at the festival. ${ }^{89}$

Aside from community building, the Latin American Heritage Festival participants sought to engage visitors with impressive performances and events. For the first year of the festival in 1974, the city welcomed New York-based music and dance revue, "Saludos Amigos '74," as well as other Latino folk singers and musicians who performed during the weekend. Additionally, the festival had an arts and crafts show, including a display of piñatas and artworks by Louisville Latinos. ${ }^{90}$ Like the German

\footnotetext{
${ }^{87}$ Ibid.; Cobas, Duany and Feagin, How the United States Racializes Latinos, 7.

${ }^{88}$ Joan Kay, "Latin Americans Rally for Festival," Courier-Journal (Louisville, KY), July 15, 1975.

${ }^{89}$ Ibid.

${ }^{90}$ Ibid.
} 
Heritage Festival, the 1975 festival received performers from the Smithsonian's American Folklife Tour. ${ }^{91}$ From the tour, Los Erandi, a six-member family ensemble from Mexico, Mariachi Tamazula de Virginio Udavi, a nine-piece instrumental mariachi band, and Duo Martinez, a dance team from Mexico, performed during the weekend. ${ }^{92}$ Contributions from the Louisville area included Dogomar Cabrera, a Uruguayan singer and guitarist, and poet and dancer Blanca Castrejan, who was originally from Mexico. There were also dances performed by Latino children, and songs prepared by Venezuelan students from the University of Louisville ${ }^{93}$ In addition to the performances, there was a Latin American fashion show of "native costumes," a piñata party, and an arts and crafts show displaying items from twenty-one different Latin American countries in the 1975 festival..$^{94}$

Food was also an important aspect to the Latino Heritage Weekend, as people often engaged in other cultures through food. The dishes for sale at the 1975 festival included pastelitos de queso, pastelitos de guayaba, empanadas de carne, arroz con pollo, tamales, and desserts. ${ }^{95}$ The pastelitos and empanadas were one of the biggest sellers at the festival. To prepare for the weekend, fifteen LAC members "filled 2,000 of the pastry circles with meat (70 pounds) or cheese (90 pounds), shredded" which were fried to order, according to Courier-Journal reporter Lillian Marshall. ${ }^{96}$ Food was definitely the pinnacle of the festival, as Ernesto Gittli said, "We were having trouble

91 "Next: Latin American Heritage Weekend," Courier-Journal (Louisville, KY), July 13, 1975.

92 Ibid.

${ }^{93}$ Kay, "Latin Americans Rally for Festival."

94 "Next: Latin American Heritage Weekend;" Kay, "Latin Americans Rally for Festival."

95 "Next: Latin American Heritage Weekend."

${ }^{96}$ Lillian Marshall, "Kentuckiana Cooks: The Specialities of Latin America," Courier-Journal (Louisville, KY), July 19, 1975. 
cooking fast enough to feed everyone," and reported that tacos and sausages both "sold out early in the day at two stands." 97

In the 1976 festival, LAC organizers continued to build outward from previous festivals, so that in each year there would be something new and exciting for visitors. The festival again admitted traveling groups, including El Mariachi Infantil from Mexico and Mi Grupo y Bomba, a Puerto Rican ensemble from New York. In addition, exhibits displayed "wood sculpture, pottery, jewelry and other handmade items" and a "South-ofthe-Border" show demonstrated "costumes" and traditional dress. ${ }^{98}$ The 1976 food options included the original menu of chorizos, tacos, arroz con pollo, and pastelitos. Festival participants also added a Spanish Mass to the weekend's festivities, which was held at the Cathedral of the Assumption. ${ }^{99}$ The 1976 festival ended the weekend with a conga, reported Swem, "a dance in which participants form an undulating line that looks like a snake."100 The 1977 festival also saw the "food, music, dance and art of the countries south of the border," with exhibits and performances from twenty-five Latin American countries, the most represented thus far at the festivals. ${ }^{101}$

Audience participation in the entertainment at the festivals became increasingly common and coverage of the entertainment increased as well. Jim Adams wrote of one instance where both adults and children were participating in the events at the Latin American Heritage Weekend in 1975:

There were two little boys, one wearing light blue and the other wearing the smallest pair of denim overalls on the Riverfront Plaza. They were

\footnotetext{
97 Jim Adams, "Rain Cools Hot Latin Spirit at Fest," Courier-Journal (Louisville, KY), July 20, 1975.

98 “Riverfront Fiesta," Courier-Journal (Louisville, KY), Aug. 8, 1976.

99 “Heritage Celebrations Continue,” Courier-Journal (Louisville, KY), Aug. 8, 1976.

100 Swem, "Latin American Heritage Weekend."

${ }^{101}$ Gregg Swem, "Latin American Heritage Weekend," Courier-Journal (Louisville, KY), June 24, 1977; Swem, “The Heritage Festivals: It's 'Vive la France' Time Down by the Old Ohio,' June 5, 1977
} 
holding both hands together and smiling and jumping up and down. Obviously, they were into what the grownups around them were doingwhich, with a bit more Latin spirit, was largely the same thing. Dogomar Cabrera of Uruguay was on stage singing and sharing the audience's attention with a number of grownups dancing an intricate step down front. The two little boys were no less enthusiastic than Cabrera, or those grownups or Blanca Esthela Castrejon of Mexico, who narrated a poem about the Mexican way of life at the festivities. ${ }^{102}$

This was important because, after all, the way to get people to enjoy the festival, come back, and buy items and food from it was through entertainment. News coverage also contributed to the festival's popularity, as Courier-Journal reporters followed the events consistently throughout the years. Articles detailed the entertainment, interviewed participants, and marketed the festival to readers; interest in the Other brought thousands to the festival annually.

Though not as numerous as the German festivals, the turnout for the Latin American Heritage Weekends was still impressive. The first year of the festival welcomed 10,000 people, with a high rise in attendance the next year at 34,000 attendees. 1976 and 1977 steadily decreased in number as 30,500 and 24,000 people attended the festivals, respectively. ${ }^{103}$ Though the festival was not as popular as other festivals, especially compared to the numbers of the German Heritage Weekend, the attendance was still dramatic, considering Latinos made up 0.4-1.4 percent of the population. ${ }^{104}$ Not only were they a small percentage of the population, though, they were also a non-Anglo ethnic group that was rather new to the city, so for thousands of people to attend the two-

\footnotetext{
102 Adams, "Rain Cools Hot Latin Spirit at Fest."

103 "Heritage Weekends," ca. 1976, Immigrants: Heritage Fairs/Weekends Reference File.

1041970 Census of Population and Housing: Louisville, KY.-IND.," U.S. Department of Commerce, 1972, 17; The census estimated that $0.4-1.4 \%$ of Louisville's population was Hispanic. This number would equal to about 1,426 to 4,990 people.
} 
day festival was significant. The attendance also shows the interest Louisvillians had in the foreign and consumable Latino cultures, as thousands showed up to eat the food and experience the festivities of communities mostly unknown to them.

Many festival participants interviewed during the festivals stressed the significance of the event as an opportunity for others to learn about American Latinos. Though entertainment was a way to draw people into the festival, and interactive elements promised them a good time, there were still educational moments at the festival. In fact, through dances, music, and fashion shows, people were able to learn about Latino cultures. This was important to many Latinos in Louisville, as many people were oblivious to these communities. Gittli stated in 1975 that the festival was "a good thing to do," since "when people think of South of the Border, they often think only of Mexico." 105 He went on, "Most people aren't aware of the fact that Central and South America have so many countries and different cultures." 106 The festival aimed to teach others about the diversity amongst Latinos.

The mission of LAC members for the festival was to promote diversity, and to display that diversity to festivalgoers. The festivals' exhibits had sections for each country "to display arts and crafts, manufactured items and other objects typical of the country," reported Courier-Journal writer Joan Kay. ${ }^{107}$ Through such exhibits, people saw and understood the difference between individual Latino countries. Exhibits were able to show such diversity as the LAC included members "from all over Central and South America and the Caribbean." ${ }^{108}$ Food was also an avenue to exemplify Latino

\footnotetext{
${ }^{105}$ Kay, "Latin Americans rally for festival."

${ }^{106}$ Ibid.

${ }^{107}$ Ibid.

${ }^{108}$ Marshall, "The Specialties of Latin America."
} 
diversity. Eva Simmons, of the LAC, who helped create the festival menu and prepare the food, said, "We are not all the same. We are from different countries, our accents are different and we have different words for things." ${ }^{109}$ For example, she pointed out how one of options on the menu could be called an "empanada" or a "pastelillo," depending on the country of origin of the speaker. ${ }^{110}$ Ernesto Gittli also touched on this when he wrote to the Courier-Journal expressing his gratitude for the for the " 35,000 Louisvillians who were there [at the festival] in spite of rain and heat," saying, "we hope you all had a good time and enjoyed our entertainment, food and displays and we hope we gave you a taste of our Latin American Heritage." 111 That was the point for many participants: to provide others with this "taste" of Latin American cultures so that they may better understand the heritage of their Latino neighbors. ${ }^{112}$

Scholars such as Lorrin Thomas and Blanca Silvestrini, point to an emphasis on diversity as a method Latinos use to assert themselves as being legitimate in American society. As the racialization of Latinos caused them to be labeled as foreigners and outsiders in the U.S., Latinos often desire to have their cultures recognized as valid in the United States. ${ }^{113}$ However, festival participants also utilized the festivals for community solidarity and a chance to come together despite, and in spite of, the racial oppression they may have felt. ${ }^{114}$ Festivals, such as the Heritage Weekend in Louisville, permitted Latinos to put their cultures central in the activities so that they could define their

\footnotetext{
109 Ibid.

110 Ibid.

${ }^{111}$ Ernesto Gittli, “Latin American Gratitude,” Courier-Journal (Louisville, KY), July 28, 1975.

112 Ibid.

113 Thomas, Puerto Rican Citizen, 3.

${ }^{114}$ José M. Alamillo, Making Lemonade out of Lemons: Mexican American Labor and Leisure in a California Town, 1880-1960 (Champaign, IL: University of Illinois Press, 2006), 2, 5.
} 
identity. ${ }^{115}$ Though much grander in scale, a Latino festival in Washington, D.C. has been instrumental in unifying Latino immigrant groups. ${ }^{116}$ This is also true for the Louisville festival, because though it was essential to show others the diversity of American Latinos, it was also important to come together and nurture a pan-national community. The Latin American Heritage Weekend played a role in community building for a greater, pan-Latino community in Louisville. Because of the distribution of Latinos in the city, many were not aware of LAC or that there was a coalescent Latino community in the area, however the festival changed this for local Latinos. Ernesto Gittli at the end of the festival's first year said, "We had 200 names of people we didn't know here," and because of the festival in the coming years, he said, "We are finding out every day about new people who are living here." ${ }^{\prime 17}$ Latinos used the festival as a space for people to encounter each other and to become aware of the forming pan-Latino community that was taking place in Louisville. The festivals acted as a communication tool for Louisville Latinos.

American Latinos also used the festivals as placemaking in Louisville. Local Raymond Gonzalez saw the Latin American Heritage Weekend as an opportunity to publicly lay claim to his culture and to be proud of it in the public sphere, as he brought his own instrument to the festival. Courier-Journal writer, W. Curtis Riddle reported in 1976:

\footnotetext{
${ }^{115}$ Blanca G. Silvestrini, “"The World We Enter When Claiming Rights': Latinos and Their Quest for Culture," in Latino Cultural Citizenship: Claiming Identity, Space, and Rights, eds. William V. Flores and Rina Benmayor (Boston: Beacon Press, 1997), 40.

${ }^{116}$ Olivia Cadaval, "Making a Place Home: The Latino Festival," in Creative Ethnicity: Symbols and Strategies of Contemporary Ethnic Life, eds. Stephen Stern and John Allan Cicala (Logan, Utah: Utah State University Press, 1991), 205.

${ }^{117}$ Kay, "Latin Americans Rally for Festival."
} 
Music-making was not confined to the stage area. There were spontaneous concerts all over the plaza. Raymond Gonzalez and his guitar lured several persons to the fountain area of the plaza, where he was playing Spanish music. Gonzalez said he wasn't trying to "steal" any of the festival's audience but said he "just felt the urge to play." "Say, man, I'm one of the people this thing is all about," he said. "When I got here there was a break in the activities so I just came up here and started playing." 118

Gonzalez's playing of "his Spanish favorites" was one example of how festival participants came together and celebrated their own community. ${ }^{119}$ When he said that he was "one of the people this thing is all about," it is obvious that the festival was a space to recognize Latinos as an ethnic group in the United States. ${ }^{120}$ At the Latin American Heritage Weekend, Gonzalez curated his own experience at the festival, in order to publicly celebrate his identity. In everyday American society, Latinos were not traditionally allowed to celebrate or represent their cultures without being criticized for it. Flores and Benmayor argue that in cultural pluralism, people are required to express their cultures inside their home, away from the public, and to "put aside those identities and interact instead in a culturally neutral space as "Americans"” when in public. ${ }^{121}$ For Gonzalez, the festival was an opportunity to defy such standards and to come outside to perform his identity, even if he was not on the official festival program. The Latin American Heritage Festival provided a public space for Latinos to celebrate their cultures, and through it, they laid claim to Louisville as their home.

For many Latinos, the festival was also an opportunity to express feelings of longing for their countries of origin. Two Panamanian women, Elena Gordon and Gladys

\footnotetext{
${ }^{118}$ W. Curtis Riddle, "Latin Sounds, Aroma Prevail on Plaza," Courier-Journal (Louisville, KY), Aug. 15, 1976.

${ }^{119}$ Ibid.

${ }^{120}$ Ibid.

${ }^{121}$ Flores and Benmayor, Latino Cultural Citizenship, 9.
} 
Fox, attested to this, saying the festival made them homesick. According to writer Sharon Bramlett, the women also "enjoyed the festivities because they got a chance to meet other people from Panama and enjoy the cultural exhibitions." ${ }^{122}$ While the festival encouraged a pan-Latino identity, individual Latino communities were also celebrated and recognized in the festival. This celebration not only legitimized Latino cultures but also encouraged Louisville Latinos to feel represented and valuable to the cultural makeup of the city. Despite the efforts Latinos made in the Latin American Heritage Weekend, the results were only among the pan-Latino community. While a pan-national community was nurtured and Latinos asserted themselves as citizens in Louisville, racism and stereotypes continued to follow American Latinos. The Heritage Weekends were created to produce a multicultural society, and while it appeared that way at the festivals, it failed to do so outside of the festivities. Even during the festivals, Latinos were stereotyped and described in racialized ways. Louisville continued to hold Anglo Americans as the definition for a mainstream, normative culture, and those who were out of this description were left out and discriminated against. This was because racism and racialization were far deeper in Louisville's framework than a festival could overcome.

\footnotetext{
${ }^{122}$ Sharon Bramlett, "It's the Latin Beat in Full Force North of the Border This Time," Courier-Journal (Louisville, KY), June 26, 1977.
} 


\section{CHAPTER THREE}

\section{RACISM AND EXOTICISM AT THE FESTIVALS}

The 1970s were a period of changing racial negotiation in Louisville, Kentucky, so the Heritage Weekends and their promise of multiculturalism emerged at a significant moment. Festival organizers and the Courier-Journal attempted to use the festivals as evidence of cosmopolitanism and tolerance of difference, though lingering racialization and residual stereotypes challenged this framing of the Heritage Weekends. Organizers ensured the festivals sought to offer an authentic experience for festivalgoers, and as a result, festival participants had to negotiate these stereotypes. Latinos dealt with this racialization as they were especially described in derogatory terms in newspaper articles, and notably in discussions of festival food. Food served as a categorical stereotype for ethnicity and a motivator for many of the festivals, as it was a focal point in both the German and Latin American Heritage Weekends. Festival attendees exoticized the communities on display through their food choices, as well as the consuming of marginalized cultures at the festivals.

The larger racial backdrop of the city highlights the kind of racial attitudes present in the border city during the formation of the festivals. In the beginning of the $1970 \mathrm{~s}$, Louisville and Jefferson County schools felt pressure to address their failed efforts of school integration that had lingered since 1956. In 1974, the same year that the Heritage Weekends began, the school boards of Louisville and Jefferson County met to discuss a 
new plan that used busing to achieve an integrated school district, an initiative implemented in the 1975 school year. Through busing, students were assigned to certain schools so that black students made up between 12 and 35 percent in all schools. The efforts toward integration and equal education, however, came with a lot of opposition that resulted into violent acts throughout the city. ${ }^{123}$

The summer before busing began, during the second year of the Heritage Weekends, tensions were high as groups against the plan held rallies and contemplated boycotts and legal action, leading to violence at the beginning of the school year. One such group that gained momentum in this decade was the Ku Klux Klan (KKK). In July 1975, the Kentucky Taxpayers' Association held a meeting where KKK leaders spoke. At this meeting, speakers used ideas of white supremacy and discrimination as reason to oppose busing and integration. ${ }^{124}$ The meeting and the growth of the KKK proved to Jefferson County officials that anti-busers were against busing because of integration as they clung to ideas of white supremacy to make their point. On the second day of school in September 1975, violence broke out. At different high schools in the county, protesters shouted and harassed African Americans and they chanted and held signs with phrases like "Keep the niggers out of our school," "Do away with the nigs and the pigs," and "white power." ${ }^{125}$ Many of these protests turned into mobs, lighting fires, blocking traffic and violently attacking police. Police were deployed with riot gear and tear gas to break up the mobs and instill peace in the city with the help of eight hundred National

\footnotetext{
${ }^{123}$ K'Meyer, Civil Rights in the Gateway to the South, 251, 254, 256-7.

${ }^{124}$ Ben Johnson, "Big Bad Brother: Reporter Unnerved by Klan Talk-He's Part of 'Problem," CourierJournal (Louisville, KY), July 19, 1975.

${ }^{125}$ K'Meyer, Civil Rights in the Gateway to the South, 262. The Nazi party was active alongside the KKK. Some KKK members were also members of the National Socialist Liberation Party, and some protesters across the county wore Nazi symbols.
} 
Guardsmen. Tensions continued to rise as the KKK grew. Klan leadership claimed membership doubled in the area, and in one month alone, 132 people were inducted into the Klan. The KKK encouraged the boycott of public schools and threatened those who did not comply. Additionally, there was a rise in violence against African Americans and other minority groups through 1976. Inside the schools, black students experienced issues as they were subject to poor treatment, overcrowding, and unequal discipline in the primarily white schools. ${ }^{126}$ The racism fueling the busing riots and violence permeated throughout the city and occurred at the same time as the Heritage Weekends. Not only were LBC members aware of the racial tensions in the city and used the weekends to counteract these events, but the racialization of minority groups was also present in the foundation and implementation of the festivals during this time.

Planners of the Heritage Weekends looked to cultivate diversity and harmony in an increasingly pluralist city through the festival. In fact, in the summer of 1975, on the same page of the Courier-Journal that reported on the antibusing rally and the KKK rhetoric, there was a small caricature of a Latin American with a guitar and sombrero, and the schedule of the Latin American Heritage Weekend. This page contrasts antibusing, racism, and white supremacy with the prospect of multiculturalism and tolerance. However, on the other hand, the caricature on the page is culturally insensitive as it stereotyped American Latinos. The page thus shows the height of racial tensions in Louisville during the 1970s, as well as the racialization of minorities, grouped with hopes for multiculturalism in the city. The 1970s were a highly complex and tumultuous time

${ }^{126}$ Ibid., 264, 270, 271, 275. 
for the people of Louisville, and minority groups had to navigate through the Heritage Weekends while being aware of the racial tensions around them.

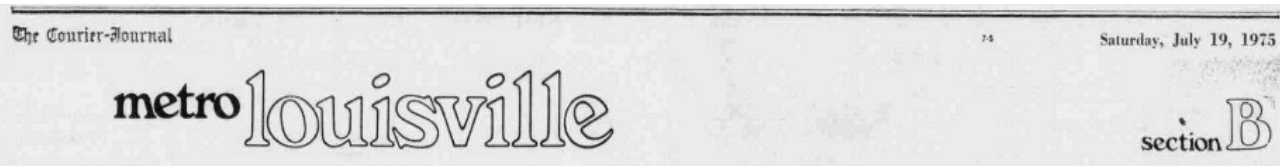

\section{Klan leaders draw support, protests at Louisville session}
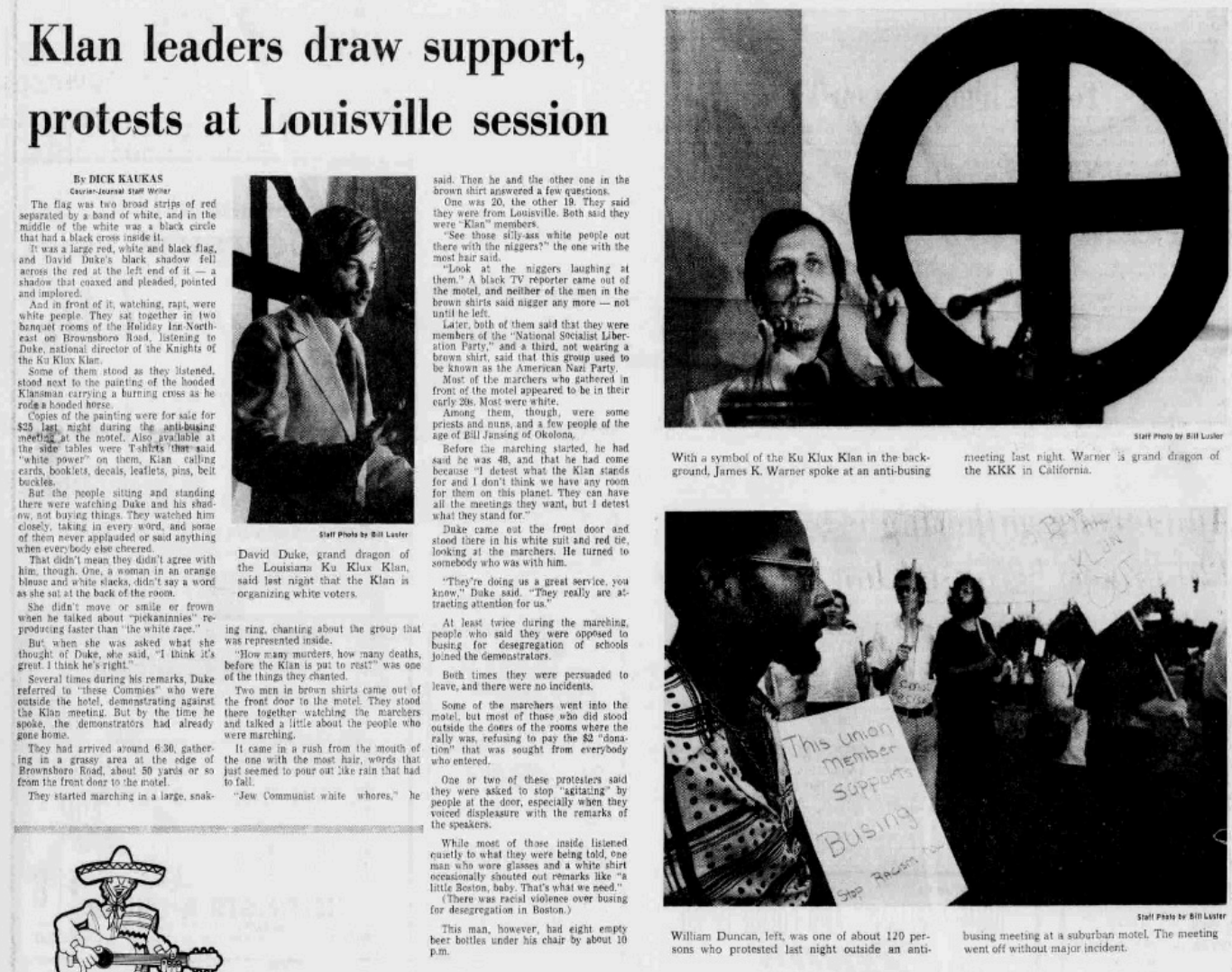

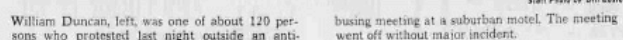

\section{Big Bad Brother}

Reporter unnerved by Klan talk-he's part of 'problem'

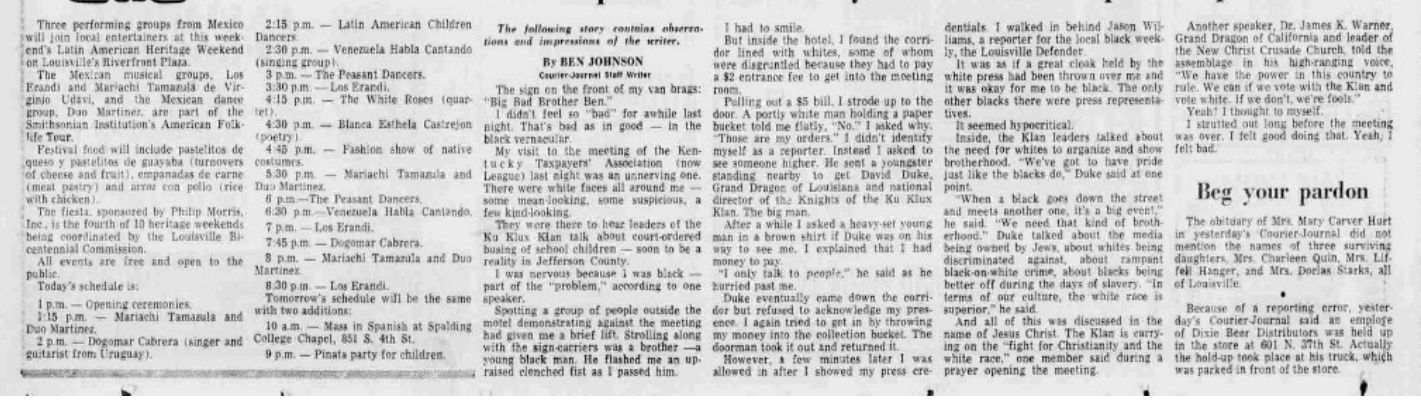

Figure 1: Courier-Journal (Louisville, KY), July 19, 1975. 
Through the Heritage Weekends, city officials promoted multiculturalism in Louisville, in the midst of racial tension and riot. According to the LBC, when they formed the Heritage Weekends, they hoped the festivals would encourage "ethnic groups to share their heritage" with the city, as well as to allow people of Louisville "to be proud of their background." 127 The goal was that the many cultural displays would contribute to acceptance and tolerance in the city. Festival organizers hoped to realize this goal, and some reports confirmed it. Dell Courtney, the special-events coordinator for the Louisville-Jefferson County Heritage Corporation, formerly known as the LBC, said of the festivals, "There were people who feared the weekends would polarize the community. What they did was show similarities." ${ }^{128}$ The proof to her, according to Joan Kay, "was the recent international Heritage Festival [in 1979], when 13 ethnic groups worked together, forgetting any political differences of the past or present." 129 Festivalgoers also saw the perspectives of the festival. After a festival in 1980, Caesar Archangel said of the festivals, "It gives a chance for people of every culture to really express themselves... that's the only way other people won't stereotype people the next time." 130 Therefore, for some, the festivals were a chance to nurture a multicultural society.

The media following the Heritage Weekends ensured that this view of harmony and plurality was reported and asserted. At the 1979 festival, John C. Long reported:

\footnotetext{
${ }^{127}$ Swem, "From many lands;" "Celebrating Your Heritage: A Weekend Downtown," Courier-Journal (Louisville, KY), July 29, 1975.

${ }^{128}$ Joan Kay, "Ms. Courtney's Louisville Legacy is a Heritage of Many Events," Courier-Journal (Louisville, KY), Sep. 14, 1979.

${ }^{129}$ Ibid.

${ }^{130}$ Michel Marriot, “A Blending of Cultures: 22,000 Jam Riverfront for Heritage Weekend," CourierJournal (Louisville, KY), May 26, 1980.
} 
A Mexican-American from Indiana came to Louisville because she was homesick for Texas. An Irish grandmother from the suburbs did a Mexican dance with a man from Poland. A Yugoslavian taught Kentucky kids a Bolivian dance that he learned in Chile. And a raven-haired flamenco dancer who set Latin hearts aflutter with fiery and sensuous movements learned in Madrid turned out to be from New York City. It was that kind of day on Louisville's River City Mall yesterday - the day of the Latin American Festival. ${ }^{131}$

In this excerpt, Long describes people by their identity so that readers can know about the multiple communities represented at the festival who celebrated in harmony. The celebration of multiculturalism was a goal of the organizers, and the article proves that this was achieved, at least for the day. This moment, though, also shows the significance of the festivals for identity groups. Here, an Irishwoman, a Yugoslavian, a Pole, an American, and a Mexican American all participated in Latino cultures. It proves that at the Heritage Weekends, identity groups were truly able to share a piece of their heritage with others, and that festivalgoers were willing to receive it. Multiculturalism was again reported in the next year in 1980 when Michel Marriott wrote, "The sound moved Demeirius Babiak to dance. The 56-year-old Ukrainian native, dressed in a traditional Hungarian costume, couldn't keep from taking to his toes when Alfredo's Combo churched out music."132 Babiak explained, "To dance to their music, it just sends you; it makes you feel terrific." 133 The Courier-Journal thus assured the LBC's goal of a multicultural, unified city was portrayed by reporting on the interplay of differing races and communities at the festivals.

\footnotetext{
${ }^{131}$ John C. Long, "Latin Lovers: International Flavor Adds Spice to Heritage Festival," Courier-Journal (Louisville, KY), July 22, 1979.

${ }^{132}$ Marriott, "A Blending of Cultures."

${ }^{133}$ Ibid.
} 
This wishful view of a unified Louisville, though, was not an accurate portrayal of the city. With race riots and hate crimes occurring in the same years as the festivals, the celebration became a way to counteract the racial tensions of the decade, although the festivals could not live up to this lofty goal. According to scholar Penny Van Esterik, festivals such as those in Louisville "could be viewed as a political or public relations statement about a community where there was a happy and well balanced ethnic mix," virtually saying to visitors that the city was a tolerant, accepting place. ${ }^{134}$ Festivals often portray ethnicity positively and provide a space where participants act as though no issues are present and that it is generally accepted to express ethnicity. ${ }^{135}$ However, this portrayal in Louisville is false and the rhetoric about the creation of the festivals, as well as the articles that promoted and reported the events, expose the reality of the city. Through this, one can see the cultural insensitivity of the festival.

When the LBC decided upon the Heritage Weekends, they laid out rules and expectations through a normative white framework and understanding. These festivals were not only to promote the diversity of the city, but they were also to provide residents with the experience of the Other. Though the festivals were promoting a space where ethnic groups could be independent and celebratory of their heritage, the reality was not multiculturalism, but cultural plurality. Scholars Flores and Benmayor discuss the problems of pluralism, arguing that though pluralism can allow for public celebration, it is often a "celebration of difference in publicly sanctioned settings." ${ }^{136}$ Pluralism often

\footnotetext{
${ }^{134}$ Penny Van Esterik, "Celebrating Ethnicity: Ethnic Flavor in an Urban Festival," Ethnic Groups 4, no. 4 (1982): 216-7.

${ }^{135}$ Ibid., 225.

${ }^{136}$ Flores and Benmayor, Latino Cultural Citizenship, 9.
} 
promotes the dominant, Anglo culture as the normative culture, and demotes ethnic groups as the Other. ${ }^{137}$ The festivals though celebrating a variety of cultural backgrounds, also positioned the exhibited communities as different. Though at the festivals, it was acceptable to be different, it was only in the setting of the Heritage Weekends that it was permitted. Even then, the cultural displays did not necessarily represent "ethnic realities" of the group. ${ }^{138}$ This was because organizers and visitors of the festivals had determined expectations of what they wanted to see of each identity group at the festival. Van Esterik argues that festivals represent a "collective ethnic fantasy that signifies something about the nature of the community to participants and observers alike." ${ }^{139}$ Identity groups represented at the festivals attempted to meet the expectations set forth through the rules of the festivals and known popular stereotypes of their communities and presented themselves as such at the festivals.

The expectations of LBC organizers were for each ethnic group to provide an "authentic" experience; however, the very foundation of authenticity reveals racialized attitudes. The Heritage Corporation presented the Weekends as having "authentic entertainment," so performing groups were "selected for authenticity." 140 Furthermore, food booths at the festivals had "strict guidelines [to] insure authenticity of food being sold." ${ }^{141}$ The LBC, and later the Heritage Corporation, made certain that the summer festivals were "authentic" and gave the "true" experience to festival attendees. ${ }^{142}$ The

\footnotetext{
${ }^{137}$ Ibid.

${ }^{138}$ Van Esterik, "Celebrating Ethnicity," 209.

${ }^{139}$ Ibid.

${ }^{140}$ The Heritage Corporation of Louisville and Jefferson County, “1978 Program Summary,” 1978, Heritage Corporation, Louisville and Jefferson County, Volume 1.

${ }^{141}$ Ibid.

${ }^{142}$ Ibid.
} 
problem with authenticity, however, is that it cannot be defined or limited. Presenting a culture as "authentic" often depicts it as static. According to Joy Neilson, "Ethnicity is dynamic; there is no pure version of ethnicity." ${ }^{143}$ Authenticity means different things for different people, so the idea of the LBC and Heritage Corporation "insuring authenticity" meant that some elements of the cultures could not be displayed according to the LBC guidelines. ${ }^{144}$ It further created a power dynamic between the city and the ethnic groups working with them, as the LBC determined what was authentic or not, real or untrue, using stereotypes to base their ideas of the festival participants.

Festival guidelines also insured festivalgoers would have a particular cultural experience. The LBC required that festival participants "create an atmosphere" that was "authentic" to the particular community. ${ }^{145}$ To achieve this, the Heritage Corporation said, "Members of groups dress in native costumes and often present parades of costumes for the audience." ${ }^{146}$ In many of the festivals, fashion shows were part of the entertainment, usually calling the native dress "costumes," to contribute to the experiences of the visitor. ${ }^{147}$ Through these displays, the point of the festivals can be understood not as an opportunity to learn about other people, but to experience, or view, culture as ethnic groups performed in front of others during the festivals. For example, the 1980 Heritage Weekends brochure explained, "This summer you will have a choice of enjoying special international foods, watching authentic costumed dancers perform or

\footnotetext{
${ }^{143}$ Joy Neilson, "Milwaukee's Ethnic Festivals: Creating Ethnic-American Heritage for Urban Ethnic Tourism," (master's thesis, University of Wisconsin, 2015), 20.

144 The Heritage Corporation of Louisville and Jefferson County, "1978 Program Summary," 1978, Heritage Corporation, Louisville and Jefferson County, Volume 1.

${ }^{145}$ Ibid.

146 Ibid.

147 "Heritage Celebrations Continue."
} 
sampling many other cultural demonstrations that pertain to their individual backgrounds." 148 Ultimately, the festivals were created for white individuals to view nonwhite cultures, so they could examine and explore the different traditions of a people.

The World's Fairs in the early twentieth century cultivated the wide practice of the ethnographic gaze, or, a kind of looking at the other. World's Fair society, argues scholar James Gilbert, helped cultivate both urban tourism and leisure. ${ }^{149}$ In that way, festival organizers used fairs to highlight the evolutionary process of civilizations, putting Western society at the top of social hierarchy, and other "uncivilized" communities at the bottom. ${ }^{150}$ Gilbert argues that through the fairs, anthropologists attempted to control the American attitude towards race, preventing Anglo Americans from being both violent and intimate towards other races, but rather to "control, enlighten, and contain the interaction between races." ${ }^{151}$ The anthropological displays of other cultures were stereotypical and idealized, and were made to represent a people, so attendants of the fair believed they were seeing authentic cultural exhibits. The fairs also asserted ideas of white supremacy and social advancement, so visitors could look at, learn about, and judge other peoples in a controlled setting. ${ }^{152}$ The World's Fairs thus set the stage for ethnic festivals in the latter half of the twentieth century, as Anglo attendants of the Louisville festivals engaged and consumed culture, while relying on ideas of stereotypes, racism, and white supremacy. As Gilberts argues, "experience is inseparable from

\footnotetext{
148 "Louisville, Kentucky Heritage Weekends 1980," brochure, 1980, Immigrants: Heritage Fairs/Weekends Reference File, Archives \& Special Collections, University of Louisville.

${ }_{149}$ James Gilbert, Whose Fair? Experience, Memory, and the History of the Great St. Louis Exposition (Chicago: The University of Chicago Press, 2009), 19.

150 Ibid., 21, 28.

${ }^{151}$ Ibid., 32.

${ }^{152}$ Ibid., 31-32.
} 
culture," and therefore the exceptionalism of Anglo Americans determined their views of others. ${ }^{153}$

Dominant stereotypes served as the basis for many of the elements of the Heritage Weekends, which in kind set expectations among festival attendees. This is especially true for the cartoon representatives of each festival weekend, found in the CourierJournal in 1975 and 1976. Accompanying festival schedules in the newspaper, there were little caricatured men (as they were all men) who had similar traits: they all held an object, and usually wore some kind of hat and traditional clothing. The Latin American caricature wore a sombrero and held a guitar, in addition to his small mustache and patterned blanket over his shoulder. ${ }^{154}$ The German cartoon, on the other hand, held a tuba while wearing lederhosen. ${ }^{155}$

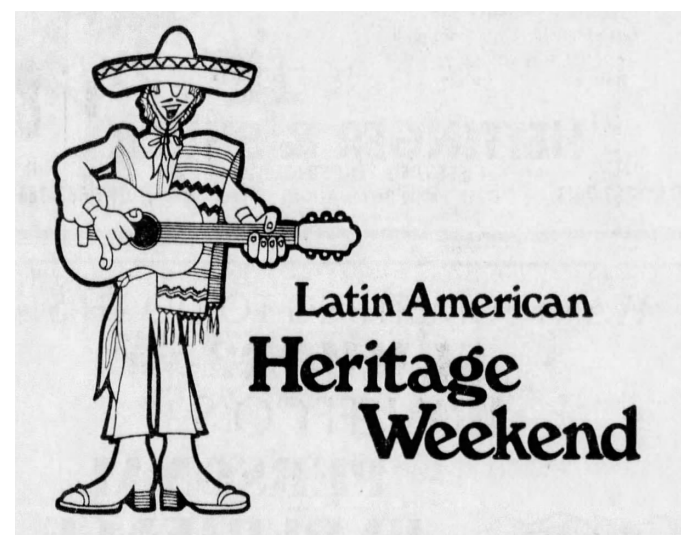

Figure 2: "Latin American Heritage Weekend," Courier-Journal (Louisville, KY), July 19, 1975.

\footnotetext{
153 Ibid., 7.

154 "Latin American Heritage Weekend," Courier-Journal (Louisville, KY), July 19, 1975.

155 "German Heritage Weekend," Courier-Journal (Louisville, KY), Aug. 6, 1976.
} 


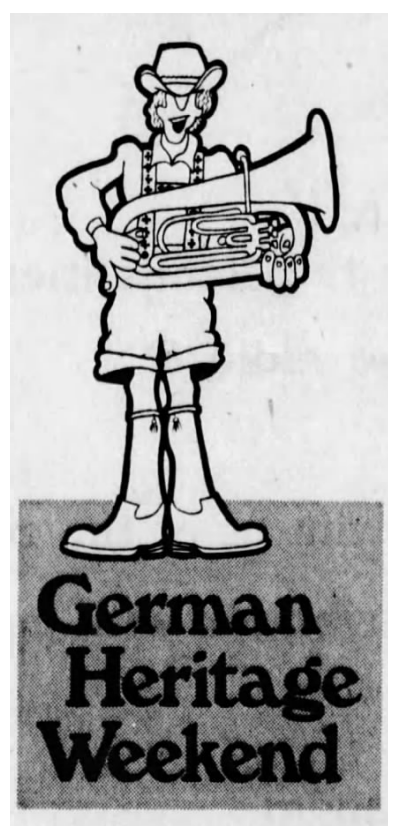

Figure 3: "German Heritage Weekend," Courier-Journal (Louisville, KY), Aug. 6, 1976.

Stereotypical caricatures depicted other ethnic groups as well. Like the German, the

Frenchman also held a tuba in his hands, but with a small mustache and a beret. ${ }^{156}$

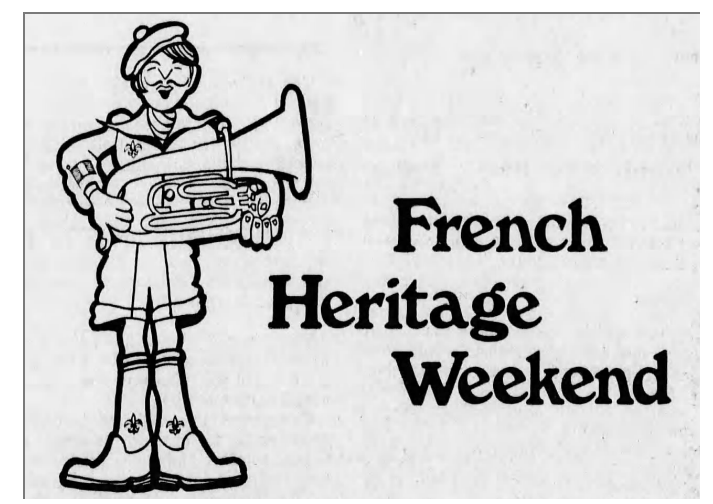

Figure 4 “French Heritage Weekend,” Courier-Journal (Louisville, KY), Sep. 28, 1975.

156 "French Heritage Weekend," Courier-Journal (Louisville, KY), Sep. 28, 1975. 
The Irishman, on the other hand, had shaggy hair and a suit, with a pipe in his mouth and a cudgel in his hands. ${ }^{157}$ The Greek caricature also had a weapon in his hands as he held a sword while wearing traditional dress. ${ }^{158}$

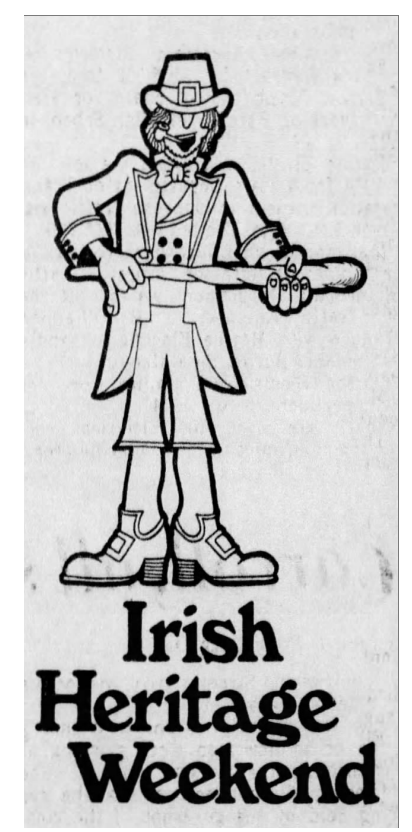

Figure 5 “Irish Heritage Weekend,” Courier-Journal (Louisville, KY), June 28, 1975.

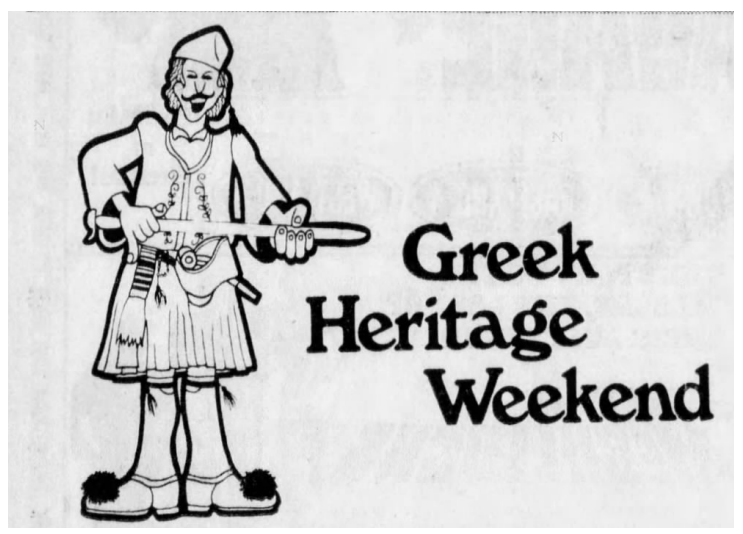

Figure 6 Greek Heritage Weekend," Courier-Journal (Louisville, KY), July 27, 1975.

157 “Irish Heritage Weekend," Courier-Journal (Louisville, KY), June 28, 1975.

158 Greek Heritage Weekend," Courier-Journal (Louisville, KY), July 27, 1975. 
The cartoon representing the Arab Heritage Weekend, was a man in traditional dress, facial hair, sunglasses, and held a hookah. ${ }^{159}$ Moreover, the African caricature held a horn while wearing sandals and traditional clothing. ${ }^{160}$

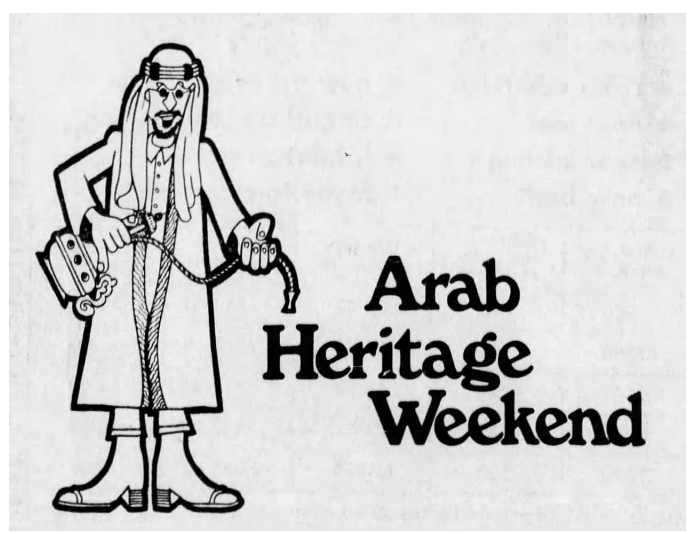

Figure 7 “Arab Heritage Weekend,” Courier-Journal (Louisville, KY), Oct. 4, 1975.

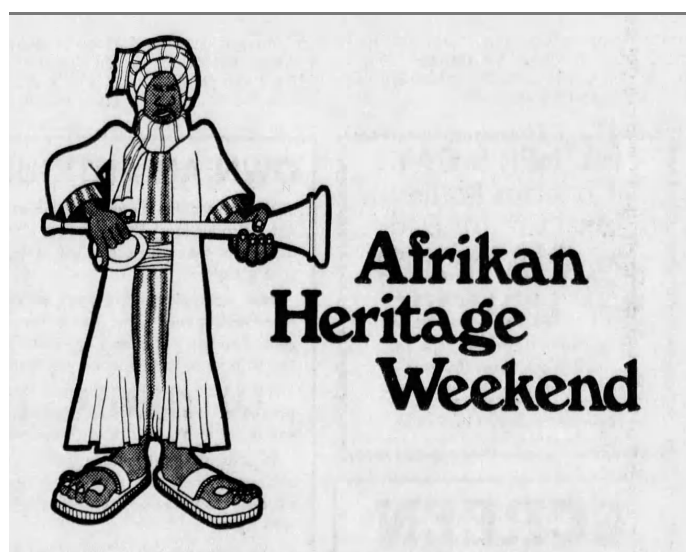

Figure 8 “Afrikan Heritage Weekend,” Courier-Journal (Louisville, KY), June 14, 1975.

These cartoons not only played on stereotypes and limited views of particular cultures, but they also played on the "racial imagination" of Anglo Americans. ${ }^{161}$ Philip Deloria argues that costumes "have extraordinary transformative qualities," and thus these stereotypical figures reaffirmed festivalgoers' expectations of ethnic groups. ${ }^{162}$ Because

\footnotetext{
159 “Arab Heritage Weekend,” Courier-Journal (Louisville, KY), Oct. 4, 1975.

160 “Afrikan Heritage Weekend," Courier-Journal (Louisville, KY), June 14, 1975.

${ }^{161}$ Philip J. Deloria, Playing Indian (New Haven, CT: Yale University, 1998), 5.

162 Ibid., 7.
} 
of this, through costume, visitors viewed festival participants as authentically ethnic, even if they were culturally assimilated. The caricatures also allowed festivalgoers to set their expectations and ideas of authenticity. If a person was going to one of these festivals, the caricature is what they would expect to see on the riverfront.

Most interesting of these advertisements is the caricature for the Afrikan Heritage Weekend; the man is portrayed as an African, and thus festivalgoers would expect African heritage at the festival. However, the weekend was more focused on African American heritage and history, with discussions on blackness, slavery, and the celebration of Civil Rights heroes. The food served was southern soul food, and musical performances consisted of jazz and soul. While there was a traditional African wedding performed at the festival, the rest of the festival focused on African American culture, unlike what the caricature portrayed. ${ }^{163}$ This discrepancy could simply be because it was easier and more acceptable to draw a stereotypical African image than that of an African American. However, giving the expectation of traditional African heritage at the festival may have appealed to African Americans of Louisville. Typically, African Americans feel more connected to their ethnic histories than European Americans, and more often identify with Africa than other minority groups do to their ancestral countries. ${ }^{164}$ Tying the festival to African culture and traditions may have encouraged more African Americans to attend the festival.

These advertisements also vividly show the bias toward European countries. Each of the white, European immigrant groups that participated in the festivals in 1975 had their own weekend festival. The Germans, Irish, French, and Greeks each had their

\footnotetext{
163 “Afrikan Heritage Weekend," Courier-Journal (Louisville, KY), June 14, 1975.

${ }^{164}$ Rozensweig and Thelen, The Presence of the Past, 139.
} 
specific weekend. However, Latinos, Arabs, and Africans, had festivals that celebrated not countries, but continents, while Native Americans did not even have a festival. In each of the non-European festivals, participants celebrated a whole continent with multiple cultures and identities in the same space and amount of time as individual European nations. These clumped together communities were thus more stereotyped than the European festivals and are proof of the racialization of non-European groups. This is thus one of the reasons festival participants of the Latin American Heritage Weekend stressed the diversity of American Latinos, as they were being lumped together in one festival. Latinos, however, also used this to their advantage when they fostered a panLatino identity through the Heritage Weekend.

Racialization through stereotypes and food especially followed the Latin American Heritage Weekends, as opposed to the German festival. In the CourierJournal, reporters often referred to the festival being "north of the border," such as the 1977 article titled, "It's the Latin Beat in Full Force North of the Border This Time." 165 By saying this phrase, reporters were emphasizing the divide between the United States and Latin American countries. Furthermore, the phrase also refers most closely to Mexico, leaving out the many different countries that were represented at the Latin American Heritage Weekend.

Latinos were also described in derogatory ways in the Courier-Journal. In one instance, Michel Marriott described a Mexican woman visiting her ill father during the time of the festival by her physical features: "Christina DeValazquez gazed out into the western sky and thought of Mexico and home. Her round, fudge-brown face was shaded

${ }^{165}$ Bramlett, "It's the Latin Beat in Full Force North of the Border This Time." 
by a large, straw [sombrero.] She wore a brightly colored Mexican dress, typical of the southern part of her land." 166 This thorough description of DeValazquez exhibited her as an outsider in a stereotypical and exoticized manner. By commenting on her skin color and the clothes that she was wearing, Marriott made the woman seem exotic and played with ideas of the Other.

Aside from exoticism, spicy rhetoric remained the most common way to describe the Latino festival in the Courier-Journal. This kind of anti-Latino rhetoric has been used in the U.S. for a century, and according to historian Katherine Massoth, in the Southwest along the U.S.-Mexico border, Anglos "distanced the United States from Mexico by generalizing New Mexican foodways as spicy, dirty, and suspect." 167 Therefore, Massoth argues, "Anglos used their eastern and middle-class constructions of cleanliness and spice to police the boundaries between New Mexican bodies and their own 'pure,' white bodies." 168 Referring to Latinos as "spicy" has long been a theme in the United States that characterized American Latinos in a negative way. ${ }^{169}$ This rhetoric was a constant in the Courier-Journal, with headlines such as "Rain cools hot Latin spirit at fest," and "Latin Lovers: International flavor adds spice to heritage festival." ${ }^{170}$ Furthermore, descriptions of the festival included the festival having "lots of hot, spicy food," and the music being "as Mexican as beanless chili and as red-hot as a taco." ${ }^{171}$ In fact, when talking about the Latin American festival, there was an emphasis on food, whether it meant describing the

\footnotetext{
${ }^{166}$ Marriott, "A Blending of Cultures."

${ }^{167}$ Massoth, "“Mexican Cookery That Belongs to the United States," 50.

${ }^{168}$ Ibid.

${ }^{169}$ Ibid.

170 Adams, "Rain Cools Hot Latin Spirit at Fest;", Long, "Latin Lovers."

171 "Riverfront Fiesta;" Marriott, "A Blending of Cultures."
} 
festival and people or discussing one of the main attractions of the festival. This emphasis on food and spiciness in the Courier-Journal describes the fascination Anglo Americans had with Latino cultures. By the 1970s, Mexican food was popular in the United States and people enjoyed the food without having to accept the people who made it. ${ }^{172}$ This rhetoric describes the voyeurism of Anglo Americans, as they could appreciate and exoticize a food that was from a foreign people at the festivals. ${ }^{173}$

Certainly, for both the German and Latin American Heritage Weekends, food was an essential component; however, there was a marked difference. At the German festivals, food represented German American culture, and people enjoyed consuming it, but it was more complicated at the Latin American festival. For Latinos, food not only described the festival and the cultures, but they were described by food as they were constantly referred to as spicy and hot. Furthermore, Latino foods were more exotic to the Anglo festivalgoer, and therefore stereotypes and voyeurism were more common at the Latin American Heritage Weekend than at the German festival.

The lure of food at the ethnic festivals served as a stereotype of ethnicity. In a booklet for the 1979 Heritage Weekends, one of the selling points to people was that they were able to "sample exotic food and beverages." 174 There is a reason that food is important in ethnic festivals though. Van Esterik argues that ethnic identity is expressed through food, as people associate foods and dishes with certain ethnicities. ${ }^{175}$ Food can

\footnotetext{
${ }^{172}$ Gustavo Arellano, Taco USA: How Mexican Food Conquered America (New York: Scribner, 2012), 7.

${ }^{173}$ Massoth, "'Mexican Cookery That Belongs to the United States," 54.

174“"Louisville Heritage Festivals Seventy-nine," booklet, 1979, Immigrants: Heritage Fairs/Weekends Reference File, Archives \& Special Collections, University of Louisville.

${ }^{175}$ Van Esterik, "Celebrating Ethnicity," 208.
} 
become an aspect of ethnic stereotypes. ${ }^{176}$ Furthermore, the idea of the food being "ethnic," according to Olivia Cadaval, "cements the relationship between the vendor and his culture and the buyer-become tourist, who asserts his identity by consuming the cultures of others." ${ }^{177}$ So, the white tourist, or attendee, of the festival is reminded of their "whiteness" when eating food at the ethnic festival. ${ }^{178}$ In Louisville, food was a main attraction of the Heritage Weekends and festivalgoers constantly referred to food as an exciting way to engage in the displayed community. They were able to have this experience, though, because the festival provided a safe place to consume these foreign foods without having to interact deeply with the identity group of which the food belonged.

The curiosity of unique foods and of "eating the other" were displayed in the Courier-Journal articles about the festivals. ${ }^{179}$ Not only was the food described in nearly every article that discussed the festivals, but the people interviewed at the Heritage Weekends talked about it as well. In a specific segment leading up to the 1975 Latin American Heritage Festival, Lillian Marshall conducted an interview with women who were preparing food for the weekend, and included recipes for pastelillos, picadillo filling, potato pie, and chorizo in the article. ${ }^{180}$ Festival visitors also described the food as a main attraction. One woman standing in line for food at the 1975 Latin American Heritage Festival said, “I don't know what this line is for, but I just want to be able to say

\footnotetext{
${ }^{176}$ Ibid.

177 Cadaval, "Making a Place Home," 212.

${ }^{178}$ Kyla Wazana Tompkins, Racial Indigestion: Eating Bodies in the $19^{\text {th }}$ Century (New York: New York University Press, 2012), 2.

${ }_{179}$ Donna R. Gabbacia, We Are What We Eat: Ethnic Food and the Making of Americans (Cambridge, MA: Harvard University Press, 1998), 9.

${ }^{180}$ Marshall, "The Specialties of Latin America."
} 
I've had some, I guess." ${ }^{181}$ Instances like this reveal the appeal of exoticism and trying new, unusual things. By not even knowing what she was going to eat, but willing to because she wanted "to be able to say" she has had it, explains the way many people viewed food at the festivals. One advantage for festival attendees was that the festival created a safe space for people to try different foods, as "in an everyday context, these nonindustrial foodways would most likely be avoided by customers, but during festival time social, cultural, and sometimes health prohibitions are suspended," asserts Cadaval. ${ }^{182}$ The festival granted a chance for people to try different things in a safe space, and to be able to participate in that culture through food, providing them with a sense of cosmopolitanism.

Festivalgoers used stereotypes to define their food expectations and understanding of authenticity. Riddle reported in 1976, "According to one man, he only came to eat some of the 'tasty dishes.' 'I figured this would be the place to get a good taco,' Joseph King said. 'The tacos were great, but the chili didn't have a sting to it."'183 In this statement, King evaluated the quality of Latino food by his preconceived notions of what Latin American food should taste like. He touched on the spiciness expected of Latino dishes, as well as the expected authenticity of the festival and its food, as he said that the festival would be "the place" for a "good taco." 184 The food, however, did not meet his expectations, as he said that the chili was not spicy. Stereotypes not only fueled ideas of authenticity but allowed people to judge other cultures as King did at the Latin

\footnotetext{
${ }^{181}$ Adams, "Rain Cools Hot Latin Spirit at Fest."

${ }^{182}$ Cadaval, "Making a Place Home," 215.

183 Riddle, "Latin Sounds, Aroma Prevail on Plaza."

${ }^{184}$ Ibid.
} 
American Heritage Festival. King's judgmental comment, though, is because of the racialization of Latinos and their perceived inferiority to Anglo Americans.

Since food represented authenticity and stereotypes at the Heritage Festivals, eating food was thus an avenue for experiencing cultures other than the visitor's own. At the German Heritage Festival, this was especially true, as Loomis wrote, "German music has a special appeal: It makes you hungry." ${ }^{185}$ In the first year of the festival, an article in the Courier-Journal by Billy Reed read, “A good ol' German time was had by all. This wasn't surprising, of course, because if there's anything Germans are good at, it's doing fun things like eating strudel... and of course, drinking beer." ${ }^{186}$ This statement reveals the way the festival attendees interacted with German culture at the festival. Not only was the food a critical element of the festival, but according to the writer, it described the German people. Festivalgoers essentialized the complex culture of German Americans to their food. Furthermore, this statement reduced Germans and their history and accomplishments to strudel and beer.

Ultimately, the Heritage Weekends played on ethnic uniqueness, difference, and exoticism. Barbara Kirschenblatt-Gimblett usefully found that, "A key to the appeal of many festivals, with their promise of sensory saturation and thrilling strangeness, is the satiable and promiscuous human appetite for wonder." ${ }^{187}$ Thus, the festivals contributed to stereotypes to feed that "human appetite" with food, costume, and entertainment as tangible and commodified culture to create an overall "authentic" experience for visitors

\footnotetext{
${ }^{185}$ Loomis, "German Sprinkling."

${ }^{186}$ Billy Reed, "Festive Occasion: Louisville's Germanic heritage is celebrated on Belvedere," CourierJournal (Louisville, KY), July 14, 1974.

${ }^{187}$ Barbara Kirshenblatt-Gimblett, Destination Culture: Tourism, Museums, and Heritage (Berkeley: University of California Press, 1998), 72.
} 
at the festival. ${ }^{188}$ Stereotypes and cultural insensitivity was thus a foundational element of the festivals as the culture of the Other was consumed.

Furthermore, analyzing the rhetoric around the festivals provides more nuance to our understanding of race relations in Louisville during this period. Latinos were subject to insensitive language and ideals more often than German Americans, though the cultures at both festivals were literally consumed by festival attendees. This is due to the acceptance of German Americans as white Americans in Louisville, while the general Anglo American population rejected Latinos and other people of color. The Latin American Festival constructed Latinos as outside the arc of assimilation, and as a result played an active role in perpetuating racial hierarchy in the city.

${ }^{188}$ Ibid. 


\section{CHAPTER FOUR}

\section{PUBLIC HISTORY AND HERITAGE AT THE FESTIVALS}

The Heritage Weekends, though with their problems of racialization and stereotyping, also benefitted the respective communities that participated in the festivals. At each festival, attendees learned about cultures different from their own, and the festivals reproduced and celebrated cultural heritage. Although subjugated to stereotypes of racial difference, festival participants also claimed agency over their own cultural interpretation, taking cultural ownership of the public presentation of their heritage. At the same time, German Americans asserted and normalized their assimilated status, presenting their heritage as static, in the past, and a relic to be revisited after assimilation. Because of their difference in assimilation and immigration, it was more difficult for Latinos to negotiate their claim to the city, and therefore used objects such as the sombrero to establish their own interpretation of an American identity. The curation of an American identity and the prospect of multiculturalism were incredibly complex though, as racism and the realities of Louisville's racial strife worked against ethnic groups in the city.

At the same time that the heritage festivals emerged across the country and in Louisville, other shifts in authorship and ownership in cultural heritage were emerging. Individual participants of the communities represented in the Heritage Weekends participated in educating the public and acted as "proto-public historians," as one scholar 
has called identity-based groups who actively cultivated their own heritage. ${ }^{189}$ The festivals occurred at the same time that the public history movement emerged, or when public history became a prominent field. Organizers of the festivals dealt with similar questions to those working in the burgeoning field of public history. Public history by definition is "history beyond the walls of the traditional classroom" and is "history that is applied to real-world issues," and public historians often use collaboration in their work to involve and empower communities. ${ }^{190}$ In defining one of the field's central tenets of shared authority, scholar Michael Frisch has highlighted "the very real authority" of communities. ${ }^{191}$ A kin to Frisch's definition, agents of heritage at the festival who represented and displayed their culture were acting as a kind of public historian as they claimed authority over their heritage and brought it to the public sphere. In the German Heritage Weekends, festival participants curated exhibits to display a fixed and apolitical view of their heritage. Meanwhile, Latinos at the Latin American Heritage Weekend used performances and entertainment to display their diversity, while also laying claim to the city as a pan-national community. Though festival participants may have not seen themselves as historians, they were actively expressing, and therefore preserving, their culture and history.

For the German Heritage Weekend, much of the festival focused on traditional German culture, invoking a static and depoliticized German past. Music and dance

\footnotetext{
${ }^{189}$ Lara Kelland, Clio's Foot Soldiers: Twentieth-Century U.S. Social Movements and Collective Memory (Boston: University of Massachusetts Press, 2018), 2.

190 "What is Public History," National Council on Public History, https://ncph.org/what-is-publichistory/about-the-field/.

${ }^{191}$ Michael Frisch, introduction to A Shared Authority: Essays on the Craft and Meaning of Oral and Public History, eds. Michael Frisch (Albany, NY: SUNY Press, 1990), xxii.
} 
performances represented that of the eighteenth century and the exhibits included much older items, such as the traditional Christmas tree on display in the festival's first year. ${ }^{192}$ After the first three years of the festival, the exhibits became more historically based and influenced by cultural professionals, as curators from renowned institutions participated in their development. In 1977, there were multiple exhibits, one including items from the Gutenberg Museum in Mainz, Germany. This display centered around one of the first Gutenberg Bibles and the innovations of Johannes Gutenberg. ${ }^{193}$ Additionally, there was an art exhibit that year called "American Through the Eyes of German Immigrant Painters," that displayed paintings from German artists in the eighteenth and nineteenth centuries. ${ }^{194}$ The goal of the exhibits evolved into showing the importance of German culture and its contributions to American society, specifically in Louisville. This was different from other festivals, specifically the Latin American festival, as other exhibits displayed objects that represented present-day cultures. German festival exhibits, though, had a specific motive to show an older, more historical view of their culture so that festivalgoers would see these exhibits and think of German Americans as having a place in Louisville society for a long time, rather than the evil, fascist Germans that destroyed lives only a few decades before.

For American Latinos, the festivals served as a way to convey their cultural heritage to a broad public in response to the prevalent stereotype attributing Latinos as being only Mexican. Festival participants curated fashion shows, food, and exhibits, so that festivalgoers were able to see over twenty different countries represented by the

\footnotetext{
192 "Achtung! Song, Dance, Food at German Fest."

${ }^{193}$ Finley, "Typecast: Gutenberg Bible Joins German Heritage Show."

194 "German-heritage Weekend;" Swem, “The Heritage Festivals: It's 'Vive la France' Time Down by the Old Ohio."
} 
LAC. Through the festival, Latinos were able to assert their distinct, individual identities, while also coming together as a pan-Latino group. By celebrating the Latin American Heritage Weekend together, building up the Latin American Club, and understanding common struggles, such as racialization, Latinos were able to unite, despite emphasizing their cultural differences to the festival public.

Ethnic festivals, such as the Louisville Heritage Weekends, also created an environment for cultural preservation. These festivals reinforced "the need to practice and preserve ethnic heritage," argues Neilson. ${ }^{195}$ Having a public space in Louisville to celebrate heritage helped to confirm to participants that their history was something that should be valued and remembered. Instruments of heritage at festivals, including performances, activities, and exhibitions not only showed the presence of heritage, but they "[added] value to the cultural forms they perform, teach, exhibit, circulate, and market," says Kirshenblatt-Gimblett. ${ }^{196}$ Festival participants preserved their culture through the public remembrance and practice of it at the festivals.

Through their freedom to curate the festivals, participants expressed their identity in their own terms. Joy Neilson argues that festivals and ethnic displays involve the "conscious construction of an ethnic identity, often based on the political and social agendas" of each group. ${ }^{197}$ Neilson asserts that there is a reason for the way ethnic groups choose to be represented at public festivals. For the Louisville festivals, the LBC ensured that identity groups would have agency in the way they told their stories. The executive director of the LBC, John Guthrie, said in an interview that while the LBC funded the

\footnotetext{
${ }^{195}$ Neilson, "Milwaukee's Ethnic Festivals," 55.

${ }^{196}$ Kirshenblatt-Gimblett, Destination Culture, 156.

${ }^{197}$ Neilson, "Milwaukee's Ethnic Festivals," 1.
} 
festivals, the individual community members were in charge: “They've put it together not us. It's their expertise, backgrounds and feelings." ${ }^{" 198}$ Festival participants controlled the way their history and culture was presented, based on the race relations in the city.

The German Heritage Festival sought to assert the assimilation and whiteness of their German American identity. Unlike other festivals, the German festival only displayed older, traditional items in exhibits, ignoring current Germany or the state of the country, as it was divided into East and West in the midst of the Cold War and still recovering from World War II. The Second World War was only a few decades before the festivals and German Americans wanted to distance themselves from the crimes of Nazi Germany. However, much of the cultural forms of the German Heritage Weekend activities echoed the traditional Oktoberfest, an annual festival in Munich, Bavaria, Germany since the early 1800s. The food served, the biergartens, and the emphases on beer, as well as the dress of lederhosen and dirndls, are all common and traditional elements of the Southern Germany festival, carrying through to the Louisville festival. This is not uncommon though, especially for an assimilated group like the German Americans of Louisville. The group was taking part of a symbolic ethnic identity, which is an identity based on nostalgia and ancestral customs. Neilson argues, "Symbolic ethnicity offers assimilated ethnic groups an opportunity to be part of a unique social club without losing status gained from assimilation." 199 The history local German Americans curated was intentional at the German Heritage Weekends, as it allowed them to identify with their heritage, at least for the weekend, while remaining American and white.

\footnotetext{
${ }^{198}$ Swem, "From Many Lands."

${ }^{199}$ Neilson, "Milwaukee's Ethnic Festivals," 21.
} 
American Latinos instead used the festivals as way to claim their place in Louisville despite the racism of the city. The Latin American festival focused on the diversity of American Latinos, showing to visitors that not all Latinos nor Latin American communities were the same. Kirshenblatt-Gimblett argues that agency and cultural authority "not only shows and speaks, it also does."200 Latinos asserted themselves in a way to defy certain stereotypes and to be recognized and legitimized in Louisville. This was consistent with the current race relations and tactics to support integration during the 1970s. K'Meyer argues that "traditional civil rights tactics" of rallies and protests "were now replaced by a new set of weapons," such as involvement in school board meetings and working with the schools to help students. ${ }^{201}$ These tactics were used to fight the racism prevalent in the city. Minority groups, such as American Latinos, also used the festivals as a "weapon" to fight against the racism they experienced, as well as the racism that informed the Heritage Weekends. ${ }^{202}$ In one such way, Latinos relied on the use of the sombrero to transform the stereotype so that it advantaged the group at the festival.

Because Latinos had to function within racialized narratives, they used the sombrero as a way to assert their own identity in Louisville. Historically, Gustavo Arellano argues that for Mexicans, sombreros were "markers of proud campesinos or charros... who reveled in the rewards of a hard day's work." Americans, however, have changed the meaning of the sombrero into a "happy hat," and it has become a symbol of

\footnotetext{
${ }^{200}$ Kirshenblatt-Gimblett, Destination Culture, 6.

${ }^{201}$ K'Meyer, 284.

${ }^{202}$ Ibid.
} 
drunkenness and frivolity in the U.S. ${ }^{203}$ At the Latin American Heritage Weekend festivities, Latinos and non-Latinos alike wore the hat on the Riverfront. There was even a booth at the festival that donned a twelve-foot-tall sombrero to advertise the Latino food being sold. ${ }^{204}$ The sombrero has become a symbol of Latino culture in the United States, and Anglo Americans associate it broadly with a wide range of Latin American communities. Because of this, if a person was going to a Latino festival, they would expect to see sombreros. However, the use of the sombrero was also a way for Latinos to construct their identity with the same material item. Scholar Elizabeth Chacko argues that immigrants often struggle with understanding their place in the United States, and therefore use certain cultural items to reinforce their identity in the new country. ${ }^{205}$ It was a way to affirm cultural difference while also asserting an American identity. ${ }^{206}$ So festival participants used sombrero in order to preserve the cultural item as it was repurposed and enjoyed in its own way in the United States. The festival's use of the traditional hat represented an expression of a new Latino identity in Louisville and the United States. Cadaval argues that immigrants are often faced with the need to establish their identity and to define what "American" means to them. ${ }^{207}$ American Latinos used the festival as a space to assert their identity and heritage in Louisville through their curation of objects and performances.

\footnotetext{
${ }^{203}$ Gustavo Arellano, "Sombreros Over the South: What lies beneath the happy hat," Southern Foodways Alliance, https://www.southernfoodways.org/sombreros-over-the-south/.

${ }^{204}$ Adams, "Rain Cools Hot Latin Spirit at Fest."

${ }^{205}$ Elizabeth Chacko, "La Fiesta DC: The Ethnic Festival as an Act of Belonging in the City," Journal of Intercultural Studies 34, no. 4 (August 2013): 444-5.

${ }^{206}$ Ibid.

${ }^{207}$ Olivia Cadaval, Creating a Latino Identity in the Nation's Capital: The Latino Festival (New York: Garland Publishing, 1998), 8.
} 
Louisville Latinos utilized the space of the Latin American Heritage Weekends to come together, form an identity, and nurture a pan-Latino community, a shift that was emerging across the United States. Flores and Benmayor argue that "cultural citizenship" consists of individuals "incorporating themselves into U.S. society, while simultaneously developing specifically Latino cultural forms of expression that not only keep identity and heritage alive but significantly enrich the cultural whole of the country." ${ }^{208}$ Louisville Latinos were doing exactly this, using placemaking in Louisville as a tool to become cultural citizens of the United States. In contrast to the racialization of Latinos that labels them as foreigners despite their citizenship status, cultural citizenship defines Latinos who have used their culture to lay claim to U.S. society. At the Latin American Heritage Weekend, Latinos utilized their tangible culture to assert their place and create their own version of an American identity. Through cultural citizenship, Latinos established and presented themselves as a prominent, pan-national identity group in Louisville.

Constructing community and identity allowed Latinos to create feelings of familiarity in a foreign and sometimes hostile society. Many of the participants interviewed commented that the festival made them "feel at home." ${ }^{209}$ Maggie Riley, a local who went to one of the heritage festivals said to a reporter, "I think that's really nice - don't you - that people come here and we can see their cultures. It's very touching. [The festival] gives them a chance to show other people where they've come from. Maybe they are a little homesick. Maybe they don't get a chance to talk about their countries very often." ${ }^{210}$ Even though Riley was a festival attendee, she was still able to

\footnotetext{
${ }^{208}$ Flores and Benmayor, Latino Cultural Citizenship, 2.

${ }^{209}$ Mariott, "A Blending of Cultures."

${ }^{210}$ Long, "Latin Lovers."
} 
see the significance of the festival for the ethnic communities in the city. Her comments reflect a growing tolerance of immigrant cultures and the increasingly cultural pluralistic quality of urban life in the latter twentieth century.

Through the curation of heritage at the Heritage Weekends, ethnic groups created a space to negotiate ideas about Americanness and citizenship. Unassimilated ethnic groups used the festivals as placemaking as they asserted their identity in American society while still holding on to their values. This is distinct from the experience of German Americans, who felt enormous pressure to erase all aspects of their German identity during the early part of the twentieth century, so during the festivals, they instead presented themselves as assimilated Americans.

The Heritage Weekends, as an attempt at articulating multiculturalism during the bicentennial and in the aftermath of the civil rights and cultural movements of the $1960 \mathrm{~s}$, certainly facilitated the recognition of cultures in the public sphere. The social movements of the 1960s had laid the foundation for bicentennial organizers to encourage the national festivities to "encompass all American history" including "our forgotten people," or those minorities often left out of the history books. This was because through the cultural movement, there was a greater demand by minorities to be recognized as legitimate citizens in the United States. ${ }^{211}$ Scholar Mick Moloney argues that during the national bicentennial celebrations, they were also "legitimizing ethnicity in a way that

${ }^{211}$ M. J. Rymsza-Pawlowska, History Comes Alive: Public History and Popular Culture in the 1970s (Chapel Hill: University of North Caroline Press, 2017), 12-13. 
contrasted sharply with the notion of Anglo American conformity that has been instilled into American official ideology."212

The festivals mark a time in American history where it was acceptable to celebrate ethnicity and being different without being labeled unpatriotic or unAmerican. ${ }^{213}$ Local Albert Gettris confirmed these feelings, saying in an interview at one festival, "People come out of their little environments when they used to be afraid, to identify themselves other than American. I'm an American, but I'm still proud I'm from Germany." ${ }^{214}$ While Gettris did not feel as though he needed to hide his heritage, the Louisville man mentioned that others felt as though they could only assert themselves as "American." However, that changed as festival participants used the public space of the festival to create their own identity in Louisville.

As there were positive aspects of the festivals, Louisville and the communities represented found many benefits from the weekends. The University of Louisville and the Jefferson County Board of Education received a grant to implement "a full program of Ethnic Heritage Studies in pilot schools in Jefferson County." ${ }^{215}$ In addition, a large number of schools used "members of Heritage Weekend groups as resources for classroom studies and events." ${ }^{216}$ The people of Louisville benefitted greatly from the Heritage Weekends, and though harmony may not have been in sight, an increased effort of inclusion and education was beginning. Furthermore, specific ethnic groups in the area benefitted. The Italian American Association was reactivated after the first Italian

\footnotetext{
${ }^{212}$ Mick Moloney, "Irish-American Festivals," in Making the Irish American: History and Heritage of the Irish in the United States, eds. J.J. Lee and Marion R. Casey (New York: New York University Press, 2006), 426-7.

${ }^{213}$ Ibid., 427.

${ }^{214}$ Marriott, "A Blending of Cultures."

215 "Heritage Weekends," ca. 1976, Immigrants: Heritage Fairs/Weekends Reference File.

${ }^{216}$ Ibid.
} 
Heritage Weekend in 1974. For Irish Americans, a sister organization to the Roman Catholic Ancient Order of Hiberians was formed. Among the Greek community, a youth group, named the Hellenic Youth Association, was formed. And the Greek Orthodox Church of the Assumption was able to end their mortgage after the profits from the 1974 and 1975 Heritage Weekends. The Latin American Club of Louisville doubled in only two years, and membership in French organizations also increased. Annual feasts also became a tradition for Irish, Greek, Italian, and Arab communities, as a result of the Heritage Weekends, and several communities, including the Irish, Italian, Arab, Greek, and Latin American, formed dance and performance groups. ${ }^{217}$ Despite the racialization of the Heritage Weekends, individual community and ethnic groups greatly benefitted from the festivals. Ethnic groups used the moment of the Heritage Weekends as placemaking in order to create organizations and public pride within their communities. The festivals were the perfect opportunity for festival participants to establish themselves and their identities in the city of Louisville. Through the Heritage Weekends, assimilated groups used their heritage primarily as an assertion of their identity and connection to their cultural heritage. However, Latinos also used the festivals for other cultural work, as they nurtured a pan-Latino community in Louisville.

The Heritage Weekends proved to be meaningful to Louisville as the city government benefitted from the festivals. Overall, the first three years of the festivals, from 1974 to 1976 , saw 3,000 volunteers, and over 1,250,000 visitors. ${ }^{218}$ Below is the attendance recorded for the first four years of the festival.

\footnotetext{
${ }^{217}$ Ibid.

218 “Heritage Weekends," ca. 1976, Immigrants: Heritage Fairs/Weekends Reference File.
} 


\begin{tabular}{|l|l|l|l|l|}
\hline & 1974 & 1975 & 1976 & 1977 \\
\hline Afrikan & 20,000 & 38,000 & 62,000 & 50,000 \\
\hline Arab & 35,000 & 40,000 & 30,000 & 18,000 \\
\hline Arts and Crafts & 15,000 & 14,000 & 6,000 & $70,000(\mathrm{KY})$ \\
\hline French & 50,000 & 40,000 & 55,000 & 51,000 \\
\hline German & 30,000 & 64,000 & 90,000 & 130,000 \\
\hline Greek & 30,000 & 34,000 & 34,000 & 39,000 \\
\hline India & --- & --- & 17,000 & 15,000 \\
\hline Irish & 10,000 & 37,000 & 32,000 & 18,000 \\
\hline Italian & 45,000 & 70,000 & 57,000 & 88,000 \\
\hline Jewish & --- & --- & --- & 105,000 \\
\hline Kentucky & --- & 6,000 & 106,000 & --- \\
\hline Korean & --- & --- & --- & 18,000 \\
\hline $\begin{array}{l}\text { Labor Day } \\
\text { Weekend }\end{array}$ & 70,000 & 20,000 & 53,000 & --- \\
\hline Latin American & 10,000 & 34,000 & 30,500 & 24,000 \\
\hline Ukrainian & 30,000 & 24,000 & 28,500 & 24,000 \\
\hline Totals & 345,000 & 421,000 & 601,000 & 650,000 \\
\hline
\end{tabular}

Table 1. Comparative Attendance. ${ }^{219}$

The swelling festival attendance numbers showed to organizers that people were enjoying and taking part in the festivals. The festivals were appealing to many in Louisville, not only for the performances and good food, but also for the prospect of multiculturalism. This was proof to festival organizers that the racial strife in the city was not a constant, as festivalgoers were enjoying the culture of other communities, and thus cultural pluralism was a possibility for the city. In turn, the festivals became a fixed component of the city's summer programming. A 1980 brochure for the festivals confirmed how meaningful the festivals were: "The Heritage Weekends have been an important part of Louisville's character since they began in 1974." ${ }^{" 220}$ The festivals became part of the "summer tourism

\footnotetext{
${ }^{219}$ Ibid.

220 “Louisville, Kentucky Heritage Weekends 1980," 1980, Immigrants: Heritage Fairs/Weekends Reference File.
} 
programs," and brought in people from around the world, whether to perform or attend. ${ }^{221}$ According to a report by LBC in 1976-77, “Alitalia, Aeromexico, and a German/American tour broker in New York have asked for assistance in arranging package tours for appropriate weekends."222 Throughout the United States during this time, festivals became a way to encourage tourism. ${ }^{223}$ This contributed to additional profit for the city of Louisville, as well as part of the downtown revitalization program to make the area a source of "community pride and new tax revenue."224 Downtown revitalization was desired by city governments because many people considered inner cities as "zones of poverty, crime, and decay" as a result of white flight, the rise of suburbia, and manufacturer abandonment. ${ }^{225}$ Thus, the urban crisis gave way to downtown revitalization and the need to improve both public opinion and revenue. Louisville responded to this need with new downtown programs, such as the Heritage Weekends.

Louisville utilized both heritage and ethnic tourism during the Heritage Weekends to engage locals as well as tourists through the celebration of heritage. Heritage tourism is based on nostalgia and ethnic tourism promotes "the display of an active ethnic other that exists within the space of the urban metro area," explains Neilson. ${ }^{226}$ Moreover, while there are benefits to ethnic tourism, such as community building and ethnic pride, there are also negative effects, such as the demand for authenticity and the expectations

\footnotetext{
221 Swem, "From Many Lands."

222 "Heritage Weekends," ca. 1976, Immigrants: Heritage Fairs/Weekends Reference File.

${ }^{223}$ Kirshenblatt-Gimblett, Destination Culture, 61.

${ }^{224}$ G. William Kingsbury and Associates, "Downtown Revitalization Manual," Commonwealth of Kentucky, 1981.

225 Andrew Hurley, Beyond Preservation: Using Public History to Revitalize Inner Cities (Philadelphia: Temple University Press, 2010), ix, 1.

${ }^{226}$ Neilson, "Milwaukee's Ethnic Festivals," 30.
} 
that come from the tourist. ${ }^{227}$ Festivals also can give a false-sense of harmony and inclusivity. Kirshenblatt-Gimblett argues that to know a society through its festivals gives "the illusion of cultural transparency." ${ }^{228}$ So the people enjoying the festivals, as well as those looking at the festivals as an example of inclusivity and multiculturalism, gain a false sense of harmony in the city. The festivals were a response to the racial divide in the 1970s and gave hope to many in Louisville that there might be an end to the rampant racism in the city. The festivals, however, were only short moments of cultural pluralism, and even in those moments, Anglo Americans still racialized ethnic groups of the city. Festival organizers' hope that the Heritage Weekends would turn Louisville into a multicultural society was unrealistic, and yet they continued to show the positive, culturally pluralistic aspects of the festival. City officials were thus able to reject other developments to create an actual multicultural society, as the festival was all they needed to promote a multicultural society.

Due to the one-dimensional results of the festivals, Louisville's Heritage Weekends garnered national attention from other cities looking to use cultural programming as urban revitalizations. The 1976-77 report noted that the city was contacted to "help in staging similar ethnic events" in places such as Norfolk, VA, Portland, OR, Rochester, NY, and Portsmouth, NH. Furthermore, the Louisville festivals were featured in Architectural Record in the summer of 1976 "as an example of events held in 'open spaces." ${ }^{229}$ The bicentennial was thus a timely moment for cities to hold festivals and celebrations of heritage. Louisville was at the forefront of this movement.

\footnotetext{
${ }^{227}$ Neilson, "Milwaukee's Ethnic Festivals," 18, 19, 30.

${ }^{228}$ Kirshenblatt-Gimblett, Destination Culture, 62.

229 “Heritage Weekends," ca. 1976, Immigrants: Heritage Fairs/Weekends Reference File.
} 
The city was likely a leader for others at it was a more progressive Southern city dealing with overt racism at the time, therefore the works of the Heritage Weekends were created to counteract the racial tension and shine a multicultural light on the city.

The Heritage Weekends were rather successful for the city, financially as well as the appearance culturally pluralistic society. Toward the end of the 1970s, the Heritage Weekends grew into the four-day International Heritage Festival, where all ethnic groups involved shared the Riverfront, and the festival continued until 1986. In 2003, a revamped international festival, called WorldFest, began with the basic principles of the Heritage Weekends from the 1970s. Because of Louisville's place in the United States and its liberal nature, it continues to strive to be a progressive Southern city.

The realities of Louisville's multicultural society were, however, disappointing. The Heritage Weekends during the 1970s, though with good intentions, were based on stereotypical imagery and racialized ideas. Ostracized groups such as Latinos engaged in a pan-national community, however they were still left out of normative, mainstream society. Latinos, like other minority groups of Louisville, were discriminated against while Anglo Americans discussed them in derogatory terms. Therefore, their claim to an American identity was highly complex. While Latinos recognized their culture in the public sphere and began to create their version of an American identity through cultural citizenship, they were still rejected by normative American society in Louisville.

The racial tensions and urban decline in the 1970s caused people of Louisville to embrace the Heritage Weekends and the prospect of cultural pluralism. As downtown revitalization and urban renewal became popular in cities across the country, Louisville used the Heritage Weekends to revitalize its downtown. However, because of how deep 
the racial divide in Louisville was, going back decades and even centuries, the idea of cultural pluralism was never truly realized. While the twenty-first century Louisville is diverse "with over 100 languages spoken in Louisville public schools and 35 percent of the city's population growth over the past 16 years coming from international residents from over 150 different countries throughout the world," Louisville is still segregated by race and identity. ${ }^{230}$

There is, however, hope for a more inclusive society, in both Louisville and the United States. Celebrating heritage and recognizing individual communities are essential for ethnic groups to establish themselves and negotiate their place in U.S. society. Immigrants are the foundation of the United States. As Flores and Benmayor wrote:

This country is strengthened, not weakened, by the vibrancy brought to it by immigrant and non-white communities. The United States has thrived not because of its efforts at cultural homogenization, but despite them. What is more, rejection of difference prevents us as social scientists and as citizens from understanding the highly complex world in which we reside. Rather than "disuniting America" or tearing apart its "social fabric," difference produces new cultural forms that, in fact, help define American - and have done so throughout its history. ${ }^{231}$

Though Louisville has yet to realize its multicultural society, ethnic groups throughout the city have still created an American identity to call their own. The Heritage Weekends thus show the importance, as well as the complexity, of celebrating heritage and culture, and creating an American identity.

\footnotetext{
230 "WorldFest," Louisville, Kentucky Government, https://louisvilleky.gov/government/cityevents/worldfest.

${ }^{231}$ Flores and Benmayor, Latino Cultural Citizenship, 5.
} 


\section{REFERENCES}

Published Sources

“1970 Census of Population and Housing: Louisville, KY.-IND.," U.S. Department of Commerce, 1972.

Alamillo, José M. Making Lemonade out of Lemons: Mexican American Labor and Leisure in a California Town, 1880-1960. Champaign, IL: University of Illinois Press, 2006.

Alexander, Ronald R. "Henry Watterson and World War I." The Filson Club History Quarterly 52, no. 3 (July 1978): 251-262.

Arellano, Gustavo. "Sombreros Over the South: What lies beneath the happy hat." Southern Foodways Alliance. https://www.southernfoodways.org/sombrerosover-the-south/.

- Taco USA: How Mexican Food Conquered America. New York: Scribner, 2012.

Baldwin, Thomas P. "The Public Image of Germans in Louisville and in Jefferson County, Kentucky, 1840-72." Yearbook Of German-American Studies 29, (January 1994): 83-90.

Bayor, Ronald H. “Another Look at 'Whiteness': The Persistence of Ethnicity in American Life.” Journal of American Ethnic History 29, no. 1 (2009): 13-30.

Cadaval, Olivia. Creating a Latino Identity in the Nation's Capital: The Latino Festival. New York: Garland Publishing, 1998.

- "Making a Place Home: The Latino Festival." In Creative Ethnicity: Symbols and Strategies of Contemporary Ethnic Life, edited by Stephen Stern and John Allan Cicala, 204-222. Logan, Utah: Utah State University Press, 1991.

Chacko, Elizabeth. "La Fiesta DC: The Ethnic Festival as an Act of Belonging in the City." Journal of Intercultural Studies 34, no. 4 (August 2013): 443-53.

Cobas, José, Jorge Duany and Joe R. Feagin. Introduction to How the United States Racializes Latinos: White Hegemony and its Consequences, 1- 14. Edited by José Cobas, Jorge Duany and Joe R. Feagin. Abingdon, UK: Routledge, 2009. 
Deloria, Philip J. Playing Indian. New Haven, CT: Yale University, 1998.

Flores, William V. and Rina Benmayor. Introduction to Latino Cultural Citizenship: Claiming Identity, Space, and Rights, 1-23. Edited by William V. Flores and Rina Benmayor. Boston: Beacon Press, 1997.

Frisch, Michael. Introduction to A Shared Authority: Essays on the Craft and Meaning of Oral and Public History, xv-xxiv. Edited by Michael Frisch. Albany, NY: SUNY Press, 1990.

Gabbacia, Donna R. We Are What We Eat: Ethnic Food and the Making of Americans. Cambridge, MA: Harvard University Press, 1998.

Gilbert, James. Whose Fair? Experience, Memory, and the History of the Great St. Louis Exposition. Chicago: The University of Chicago Press, 2009.

Holli, Melvin G. "German-American Ethnic Identity from 1890 Onward: The Chicago Case." The Great Lakes Review 11, no. 1 (1985): 1-11.

Hurley, Andrew. Beyond Preservation: Using Public History to Revitalize Inner Cities. Philadelphia: Temple University Press, 2010.

Jacobson, Matthew Frye. Barbarian Virtues: The United States Encounters Foreign Peoples at Home and Abroad, 1876-1917. New York: Hill \& Wang, 2001.

- Whiteness of a Different Color: European Immigrants and the Alchemy of Race. Cambridge, MA: Harvard University Press, 1999.

Joseph, Miranda. "Community." In Keywords for American Cultural Studies, edited by Bruce Burgett and Glenn Hendler, 57-60. New York: New York University Press, 2007.

Kelland, Lara. Clio's Foot Soldiers: Twentieth-Century U.S. Social Movements and Collective Memory. Boston: University of Massachusetts Press, 2018.

Keller, Jane K., Joseph R. Reinhard and C. Robert Ullrich. "Germans." In The Encyclopedia of Louisville, edited by John E. Kleber, 338-339. Lexington: University of Kentucky Press, 2000.

Kenny, Kevin. "Race, Violence, and Anti-Irish Sentiment in the Nineteenth Century." In Making the Irish American: History and Heritage of the Irish in the United States, edited by J.J. Lee and Marion R. Casey, 364-378. New York: New York University Press, 2006.

Kingsbury, G. William and Associates. "Downtown Revitalization Manual." Commonwealth of Kentucky, 1981. 
Kirshenblatt-Gimblett, Barbara. Destination Culture: Tourism, Museums, and Heritage. Berkeley: University of California Press, 1998.

Kleber, John E. "Anti-German Sentiment During the World Wars.” In Germans in Louisville: A History, edited C. Robert Ullrich and Victoria A. Ullrich, 188-195. Charleston, SC: The History Press, 2015.

K'Meyer, Tracy E. Civil Rights in the Gateway to the South: Louisville, Kentucky 19451980. Lexington, KY: University Press of Kentucky, 2009.

Krock, Arthur. The Editorials of Henry Watterson. New York: George H. Doran Company, 1923.

Lagunas, Miguel. "Latin Americans.” In The Encyclopedia of Louisville, edited by John E. Kleber, 500-501. Lexington: University of Kentucky Press, 2000.

Massoth, Katherine. "“Mexican Cookery That Belongs to the United States': Evolving Boundaries of Whiteness in New Mexican Kitchens." In Food Across Borders, edited by Matt Garcia, E. Melanie Dupuis and Don Mitchell, 44-63. New Brunswick: Rutgers University Press, 2017.

Merk, Joseph T. "Catholic Schools.” In The Encyclopedia of Louisville, edited by John E. Kleber, 165-166. Lexington: University of Kentucky Press, 2000.

Moloney, Mick. "Irish-American Festivals." In Making the Irish American: History and Heritage of the Irish in the United States, edited by J.J. Lee and Marion R. Casey, 426-442. New York: New York University Press, 2006.

Neilson, Joy. "Milwaukee's Ethnic Festivals: Creating Ethnic-American Heritage for Urban Ethnic Tourism." Master's thesis, University of Wisconsin, 2015.

Rosenzwig, Roy and David Thelen. The Presence of the Past: Popular Uses of History in American Life. New York: Columbia University Press, 1998.

Rymsza-Pawlowska, M. J. History Comes Alive: Public History and Popular Culture in the 1970s. Chapel Hill: University of North Caroline Press, 2017.

Silvestrini, Blanca G. “"The World We Enter When Claiming Rights': Latinos and Their Quest for Culture.” In Latino Cultural Citizenship: Claiming Identity, Space, and Rights, edited by William V. Flores and Rina Benmayor, 39-53. Boston: Beacon Press, 1997.

Takaki, Ronald. A Different Mirror: A History of Multicultural America. Boston: Little, Brown and Company, 1993. 
Thomas, Lorrin. Puerto Rican Citizen: History and Political Identity in TwentiethCentury New York City. Chicago: University of Chicago Press, 2010.

Tompkins, Kyla Wazana. Racial Indigestion: Eating Bodies in the $19^{\text {th }}$ Century. New York: New York University Press, 2012.

Van Esterik, Penny. "Celebrating Ethnicity: Ethnic Flavor in an Urban Festival." Ethnic Groups 4, no. 4 (1982): 207-228.

Weise, Julie M. Corazón de Dixie: Mexicanos in the U.S. South since 1910. Chapel Hill, NC: The University of North Carolina Press, 2015.

Weissbach, Lee Shai. “Jews.” In The Encyclopedia of Louisville, edited by John E. Kleber, 446-449. Lexington: University of Kentucky Press, 2000.

"What is Public History?" National Council on Public History. https://ncph.org/what-ispublic-history/about-the-field/.

Wilbers, Christian. "Saxon? German? American? Negotiating Germanness and Belonging in the United States, 1935-1939." German Studies Review 39, no. 1 (February 2016): 82-110.

“WorldFest." Louisville, Kentucky Government. https://louisvilleky.gov/government/city-events/worldfest.

Yu, Henry. "Ethnicity." In Keywords for American Cultural Studies, edited by Bruce Burgett and Glenn Hendler, 103-108. New York: New York University Press, 2007.

Yúdice, George. "Culture.” In Keywords for American Cultural Studies, edited by Bruce Burgett and Glenn Hendler, 71-76. New York: New York University Press, 2007.

Unpublished Sources

Heritage Corporation of Louisville and Jefferson County. "1978 Program Summary," 1978. RG 2, box 4, accession 1981-001C, Heritage Corporation, Louisville and Jefferson County, Volume 1, 572574. Louisville Metro Archives.

Immigrants: Heritage Fairs/Weekends Reference File. Archives \& Special Collections, University of Louisville. 


\section{CURRICULUM VITA}

NAME:

ADDRESS:

DOB:

EDUCATION:

AWARDS:

\section{AWARDS:}

\section{.}

